Florida International University FIU Digital Commons

FIU Electronic Theses and Dissertations

University Graduate School

3-8-2010

\title{
Orientating, Developing, and Promoting an Islamic Christology
}

Alexander Albert

Florida International University, aalex715@hotmail.com

DOI: $10.25148 /$ etd.FI10041628

Follow this and additional works at: https://digitalcommons.fiu.edu/etd

Part of the History of Religions of Western Origin Commons

\section{Recommended Citation}

Albert, Alexander, "Orientating, Developing, and Promoting an Islamic Christology" (2010). FIU Electronic Theses and Dissertations. 171.

https://digitalcommons.fiu.edu/etd/171

This work is brought to you for free and open access by the University Graduate School at FIU Digital Commons. It has been accepted for inclusion in FIU Electronic Theses and Dissertations by an authorized administrator of FIU Digital Commons. For more information, please contact dcc@fiu.edu. 


\title{
FLORIDA INTERNATIONAL UNIVERSITY
}

Miami, Florida

ORIENTATING, DEVELOPING, AND PROMOTING AN ISLAMIC CHRISTOLOGY

\author{
A thesis submitted in partial fulfillment of the \\ requirements for the degree of \\ MASTER OF ARTS \\ in \\ RELIGIOUS STUDIES
}

by

Alexander Albert

2010 
To: Dean Kenneth Furton

College of Arts and Sciences

This thesis, written by Alexander Albert, and entitled Orientating, Developing, and Promoting an Islamic Christology, having been approved in respect to style and intellectual content, is referred to you for judgment.

We have read this thesis and recommend that it be approved.

Christine Gudorf

Erik Larson

Aisha Y. Musa, Major Professor

Date of Defense: March 8, 2010

The thesis of Alexander Albert is approved.

Dean Kenneth Furton

College of Arts and Sciences

Interim Dean Kevin O'Shea

University Graduate School

Florida International University, 2010 


\section{ABSTRACT OF THE THESIS}

\section{ORIENTATING, DEVELOPING, AND PROMOTING AN ISLAMIC \\ CHRISTOLOGY}

Alexander Albert

Florida International University, 2010

Miami, Florida

Professor Aisha Y. Musa, Major Professor

The purpose of this study is to promote research into and the development of a non-polemical Islamic conception of Jesus Christ. Before engaging the textual sources the thesis considers in some detail the historical context within which the Quranic discourse about Christ was formulated, and then some post-Quranic Christological disputes between Muslims and Christians. It also considers a broad range of Quranic data about Christ in order to identify certain primary themes in the Quran about him. Then three Quranic verses about Christ and his relationship with the Holy Spirit are analyzed through the interpretations of four classical exegetes. On the basis of their interpretations as well as the general Quranic discourse about Christ this thesis makes a limited number of positive assertions about Christ as well as suggests areas wherein further research on the specifically Islamic view of Christ can be developed. 


\section{TABLE OF CONTENTS}

CHAPTER PAGE

Introduction 1

I. The formation of the Quranic Christology 8

$\begin{array}{ll}\text { II. On the question of ad hoc revelations } & 21\end{array}$

III. Orienting an Islamic discourse with a consideration of its product as independent

IV. Quranic images of Jesus 39

V. Post-Quranic Christology: It's Polemical Context 43

VI. Post-Quranic Christology: A Matter of Theological Perspective 53

VII. Quranic Exegetes and Exegesis 56

Tabari $\quad 58$

Zamakhshari 61

Baydawi $\quad 62$

$\begin{array}{ll}\text { Al-Razi } & 63\end{array}$

$\begin{array}{ll}\text { VIII. Conclusion } & 69\end{array}$

$\begin{array}{ll}\text { BIBLIOGRAPHY } & 74\end{array}$ 


\section{Introduction $^{1}$}

This thesis will attempt to make a contribution to a non-polemical understanding of Jesus in Islam. Specifically, it will analyze the relationship between Jesus, a prophet in the Islamic view, and the archangel Gabriel, the celestial messenger between God and the prophets. Though Jesus is the central figure within Christianity, this study will not be comparative but will focus exclusively on how Jesus' association with Gabriel is portrayed in the Quran and interpreted in classical Islamic exegesis. It is hoped that this effort will contribute to the discourse on Islamic Christology. Though not a theological formulation as in the Christian tradition, an Islamic Christology is concerned with identifying the role of Jesus in his prophetic mission by expounding on specific Quranic references about him. An Islamic view of Jesus seeks to understand "the role of Christ within the divine plan of human history," ${ }^{2}$ how he served God, and in what ways he edifies mankind. The use of the term Christology in the context of this thesis is generic. The term refers to traditional Christian views of Jesus as the expected Messiah, and implies certain theological premises which are absent in the Quran and Islamic tradition. The Quran identifies Jesus as Messiah, ${ }^{3}$ but does not deal at all with soteriological issues and explicitly rejects the attribution of divinity or sonship to him.

Jesus is considered one of the most important prophets in the Islamic tradition, along with other prophets such as Abraham, Noah, Moses, and Muhammad. ${ }^{4}$ It is important for both academic appreciation and Muslim religious life that this seminal

\footnotetext{
${ }^{1}$ All translations of Quranic verses come from the translation by Majid Fakhry.

${ }^{2}$ Mahmoud Ayoub. A Muslim View of Christianity: Essays on Dialogue, ed. Irfan A Omar (Maryknoll, NY: Orbis Books, 2007), 134.

${ }^{3}$ Eleven times in Medinan verses.

${ }^{4}$ See Quranic texts 33:7, 42:13-14, and 57:26. Jesus is often spoken of alongside other prophets and the most commonly mentioned prophets in the Quran are Noah, Abraham, Moses, and Jesus. See the index to W.M. Watt, Introduction to the Quran (Edinburgh: Edinburgh University Press, 1970).
} 
prophet be understood according to the context in which the Quran was recorded and the corporate Muslim intellectual tradition. This study contributes to that end by using foundational texts - the Quran, traditions, and classical exegesis-of Islam to expound on three related Quranic verses about Jesus. In developing an Islamic Christology, the overall Quranic portrayal of Jesus and the corpus of exegetical literature on Quranic verses are the necessary starting point. Later developments of the image of Jesus by Muslim thinkers are also part of the Islamic tradition. As part of a more or less continuous tradition - this thesis analyzes the Sunni traditionvarious writings about him complement and mutually elaborate one another. This complementary relationship between different Islamic discourses - exegesis, theology, and mysticism - are the foundations on which an authentic expression of Jesus can be made. I use the term authentic to indicate ideas and discourses which originate within Muslim societies and among Muslim intellectual circles, and are therefore subject to qualification, critique, and revision by Muslim scholars of various intellectual types.

Before looking at the primary sources it is necessary to ask whether Islam is capable of developing and sustaining its own Christology which in many important respects is diametrically opposed to orthodox Christian theology. After all, the Quran incorporates the central figure of Christianity while rejecting certain pivotal theological doctrines such as his divinity, the trinity, and the crucifixion. Moreover, I examine the historical circumstances of the Quranic revelations about Jesus and possible sources for the various Quranic verses about Jesus. The prophet Muhammad had contacts with Jews, Christians, and polytheists at various times during his life and to varying degrees. Some scholars have given more emphasis to these interactions than others. For some scholars Muhammad had only limited knowledge of certain 
groups and may have come into contact with their ideas, ${ }^{5}$ while for others he was intimately acquainted with a variety of ideas about Jesus and periodically included these ideas into the stream of his revelations, though haphazardly. ${ }^{6}$ This viewpoint begs the question: if Quranic datum concerning Jesus is a mixture of ideas from Christian sects on the eastern border of the Byzantine Empire, is Islamic Christology authentic? Is it independent vis-à-vis its presumed Christian sources? If so, can a coherent representation of Jesus be developed within the Islamic discourse? Also, can this Islamic discourse of Jesus be developed independently from polemics and Christian influence?

To answer these questions I will look at the religious demographics of the Near East before and during the advent of Islam. The emphasis here will be on the Monophysite and Nestorian Christian communities and what Quranic data may be traced to their teachings. In the first instance I am concerned with possible sources for the various Jesus verses and the implications this might have on the construction of a Christology within the Islamic discourse. Various verses about the conception and birth of Jesus have parallels in Christian documents, notably the apocryphal Gospels. Taking into consideration the textual parallels as well as the geographical proximity of Muhammad to Nestorian and Monophysite communities I will ask whether the meaning (read ideological and religious meaning) of the Quranic Jesus can be determined with reference to these contacts.

\footnotetext{
5 Martin Ling's Muhammad, His Life Based on the Earliest Sources (Vermont: Inner Traditions International, 1983) biography is an outstanding example.

${ }^{6}$ Important studies of these themes are Tor Andrae, Muhammad: The Man and His Faith (Salem, NH: Ayer Company, Publishers Inc., 1971); Kenneth Cragg, The Event of the Quran: Islam in its Scripture (Oxford: Oneworld Press, 1977), and Jesus and the Muslim: An Exploration (Oxford: Oneworld Press, 1985); Thomas J. O'Shaughnessy, The Word of God in the Quran (Rome: Biblical Institute Press, 1984); F.E. Peters, The Arabs and Arabia on the Eve of Islam (Ashgate Publishing Limited, 1999) and Muhammad and the Origins of Islam (Albany: SUNY Press, 1994).
} 
There is much ambiguity on this issue because we can identify the sources, or textual parallels for some verses — mainly infancy stories — but there is no single or primary source and there is no clear conceptual influence. The prophet Muhammad may have had contacts with Near Eastern Christian communities but he did not adopt their views of Jesus. Moreover, there is no way of knowing how his views on Jesus may have been affected by possible social interaction with Christian communities. It will be argued that Muhammad's portrayal of Jesus is a conceptual shift away from the Christology of any real or assumed source. So, interested students who are partial to the thesis that the Quranic images of Jesus are pious borrowings by Muhammad from various contacts can do so on intellectual and historical grounds, though the actual documentation is slight and disjointed. The qualification I want to make is that the vision of Jesus, the Islamic Christology, is not bound interpretively to the Christologies of these possible sources. Then it will be demonstrated that the development of Islam in the classical period is a continuation and institutionalization of the monotheistic vision of the Prophet as it relates to Jesus. This is evident in the efforts made by Muslim scholars and Christian converts to Islam to emphasize the humanity of Jesus in direct contradistinction to the divine status attributed to him by Christianity.

In my analysis of the historical context of the Quranic verses about Jesus it will be argued that the Quranic portrayal of Jesus is a product of the revelation and vision of Muhammad. The few really prominent textual parallels of the Quranic Jesus and Christian teachings can only have been known to the prophet Muhammad during his pre-prophetic life while traveling to Hira or Syria. It is practically impossible to develop a narrative of the development of the Quranic Christology because of this fact. The earliest Quranic verses about Jesus begin the development of a specific Islamic Christology. In later verses, when Muhammad actually had documented 
interaction with Christians during his later years in Medina, the Quran criticizes the deification of Jesus and addresses other controversial Christological issues, such as the crucifixion and whether or not Jesus announced himself as the divine son of God, the subject of verse 5:110.

Jesus is a significant prophet in Islam with a number of unique features. The main feature that distinguishes him from the Jesus of Christianity is the Quranic emphasis on his human nature in contradistinction to Christian views on his divinity. This fact is evident and paramount in early debates between informed Muslims and Christians; the issues of his divinity, as well as the trinity, were debated. Muslim authors developed certain logical methods that call into question the feasibility of assigning transcendent and immanent characteristics to Jesus. Essentially, he could not be divine and also partake in human experience. The Christology of this period, and in the context of close interaction between Muslim and Christian intelligentsia, is largely negative, i.e. it is concerned with elaborating on what Jesus is not, rather than with who he was. So it should come as no surprise that the positive discourse on Jesus - seen in anecdotes and moralizing tales popular within Sufism, which were less affected by polemical debates — tended to emphasize the transcendence of God as perceived from the perspective of Jesus, a paragon of ritual devotion and asceticism. ${ }^{7}$ While Muslim polemical literature was almost exclusively concerned with defending the absolute transcendence of God from basic Christian doctrines such as the incarnation in Jesus, the Sufi discourse about Jesus favors a view of him as an ideal ascetic and lover of God.

The way I want to approach the Islamic Jesus is by taking a thematic study of three related verses on the interrelationship between Jesus and the Holy Spirit, ruh al-

\footnotetext{
${ }^{7}$ See Tarif Khalidi, The Muslim Jesus (Cambridge: Harvard University Press, 2001). Khalidi has drawn from a number of classical sources, many from Sufi authors, to show an image of Jesus close to Sufi spiritual ideals.
} 
qudus. The choice of these verses as a starting point is rather arbitrary because one could just as well begin to develop an understanding of Jesus in Islam starting with his title 'word from God' (4:171), or try to define him in reference to his mission to the Israelites. ${ }^{8}$ I have decided to focus on the theme of Jesus and the Holy Spirit for a few reasons: the Holy Spirit is an integral part of the Quranic narrative of Jesus, from the annunciation, through his prophetic ministry, and in his time in Jerusalem. Also, an important aspect of the life and prophetic ministry of Jesus presents itself from a reading of these verses and an appreciation of their exegesis. Lastly, the independent standing of Jesus within Islam vis-à-vis orthodox or heretical Christian Christologies is solidified because the role and identity of the Holy Spirit, one-third of the Christian godhead, is differently perceived. The Holy Spirit is identified with the archangel Gabriel and his role in the ministry of Jesus is to teach him the Injil, just as he communicates the Quran to Muhammad.

The three related verses in the Quran which refer to Jesus and the Holy Spirit are: "And we gave Jesus, son of Mary clear signs and strengthened him with the Holy Spirit" (2:87 and 253); and, "Allah will say: 'O Jesus, son of Mary, remember my grace upon you and upon your mother, how I strengthened you with the Holy Spirit, so that you could speak to the people in the cradle and as an old man; how I taught you the Book, the Wisdom, the Torah and the Gospel'" (5:110). These three verses each state that Jesus was strengthened by the Holy Spirit. The term ruh, spirit, is used in a number of different ways in the general Quranic worldview and is applied to Jesus in two distinct contexts: the first has him being aided and strengthened by the Holy Spirit; ${ }^{9}$ the second indicates that Jesus originated from the breath of the divine

\footnotetext{
${ }^{8}$ Islamil Ragi al-Faruqi, Christian Ethics: a Historical and Systematic Analysis of Its Dominant Ideas (Montreal: McGill University Press, 1967), does this. He also mentions Jesus as a prototypical Sufi in one section- pp. 136-155- but is, overall, concerned more with theological and philosophical issues.

${ }^{9}$ Quran 2:87, 2:253, and 5:110.
} 
spirit. ${ }^{10}$ My analysis of the three verses mentioned above will pay close attention to this connection of Jesus with the Spirit and identifies possible claims that can be put forward about him.

This thesis will conclude by looking at classical Quranic exegesis to find out what the Quran's principle interpreters understood these verses to mean. In many ways they built upon the ideas of earlier scholars. Their entries vary in length and they make different points on each verse, but there is a general homogeneity of ideas, each of which is subject to Quranic themes and ideas. Also, they are all methodologically conservative. No one exegete reads too much into the text nor do they make irresponsible extrapolations. Moreover, they pay no attention to the theological concerns of Christianity because these verses are not addressed to Christianity. Nor are their 'incidence of occurrence', asbab al-nuzul, contextualized in debates or meetings with Christians. Moreover, the title ruh, spirit, as it was applied to Jesus (in verses 4:171 and 21:91) are not contrasted with Christian understandings, which were relatively well known in scholarly circles. ${ }^{11}$

\footnotetext{
${ }^{10} 21: 91$ and $66: 12$.

${ }^{11}$ David Thomas, Early Muslim Polemic against Christianity: Abu 'Isa al-Warraq's “Against the Incarnation" (Cambridge University Press, 2002). The introduction has useful material on the accumulation of knowledge about Near Eastern Christian sects among Muslim scholars and polemicists from informal dialogue and debate as well as the efforts of converted Christians, such as 'Ali ibn Rabban al-Ṭabarī.
} 


\section{Chapter I: The formation of the Quranic Christology}

This section will address the broad theme of historical borrowing within the Quran in relation to verses about Jesus. There is textual evidence of almost identical parallels between Quranic verses and disparate pre-Islamic near eastern literary sources, as well as terminological adaptations. ${ }^{12}$ It has been noted by a few scholars that some features of the Quranic portrayal of Jesus are a product of the non-Orthodox Christologies (non-orthodox in the sense that they did not accept the formulations of the council of Chalcedon in $451^{13}$ ) prevalent in the Near East before and during the advent of Islam. ${ }^{14}$ This position could be useful in explaining the origination of individual verses, particularly with respect to the Nestorian or Monophysite communities in the Near East.

There are two possible approaches to the issue of sources for Quranic verses. The first position - traceable to standard arguments within medieval Christian polemic on Islam $-{ }^{15}$ is that the instances of borrowing are proof that Muhammad was unoriginal. The second position, characteristically Muslim, is to play down Muhammad's contact with Christianity in order to emphasize the Quran as revelation, de-contextualized from the life of Muhammad. ${ }^{16}$ My approach to the question of sources and the implications thereof is to reorient the discourse towards a middle position whereby parallel representations of aspects of Jesus can be appreciated

\footnotetext{
${ }^{12}$ Geoffrey Parrinder, Jesus in the Quran (Oxford: Oneworld Publications, 1995); and Arthur Jeffrey's study The Foreign Vocabulary of the Quran (Leiden: Brill, 2007).

13 Neal Robinson. "Sayyid Qutb's attitude towards Christianity" in Islamic Interpretations of Christianity, ed. Lloyd Ridgeon, (New York: St. Martin's Press, 2001), 160.

${ }^{14}$ Andrae, Muhammad: The Man and His Faith; Cragg, The Event of the Quran: Islam in it's Scripture and Jesus and the Muslim: An Exploration; O'Shaughnessy, The Word of God in the Quran.

${ }^{15}$ Norman Daniel, Islam and the West: The Making of an Image (Oxford: Oneworld Press, 1993), 88, 105 .

${ }^{16}$ Hugh Goddard. A History of Christian-Muslim Relations (New Amsterdam Books, 2000), 19.
} 
historically, as a process of the dissemination of ideas and interpreted as part of the process of religious reform inaugurated by Muhammad.

The advent of Islam takes place in a semi-autonomous region between the warring Byzantine and Persian Empires. The religious milieu in Syria, Mesopotamia, and Babylon was constantly in flux as a result of changing political alliances within the Persian and Byzantine Empires and the movement of nomadic tribes. ${ }^{17}$ Many Arab tribes on the Byzantine frontier adopted Christianity and formed a strategic alliance with the Byzantines, yet there were no institutional mechanisms in place to ensure compliance with orthodoxy and a variety of theologies developed - or were brought into the region after being expelled from Byzantium -18 among them those of the Nestorians and Monophysites. ${ }^{19}$ According to Trimingham, in Mesopotamia the Aramaic world developed apart from and asserted its "spiritual freedom from Greek Christianity." ${ }^{20}$ Further, it was the development of Aramaic-speaking monastic communities that contributed to the shift from Byzantine orthodoxy to Monophysitism. These monks wrote literature and interpreted the Gospels in Aramaic, and tended to "express ideas in mythological forms." 21 They were influential in Najran in Southern Arabia, Coptic Egypt, in Abyssinia, and among Syriac-speaking Christians. $^{22}$

\footnotetext{
${ }^{17}$ Spencer J. Trimingham, Christianity Among the Arabs in Pre-Islamic Times (London: Longman Group Limited and Librairie du Liban, 1979), 150.

${ }^{18}$ Ibid., 159.

${ }^{19}$ Goddard, 15.

${ }^{20}$ Trimingham, 125.

${ }^{21}$ Trimingham, 129.

${ }^{22}$ Trimingham, 294; Goddard, 16.
} 
Another Christian sect, the Nestorians, Eastern Syrian according to Watt, were numerous in Iraq, particularly the city of Hira. ${ }^{23}$ Their church existed in the Western regions of the Persian Empire and was hostile to Byzantium. Though they were officially recognized by the Persian state, they were not a Persian church and did not seek converts from followers of "Mazdaism." According to Trimingham, they found many converts among Arab tribes in southern Iraq so that gradually the region became almost entirely Nestorian. But they did not produce their scriptures or other religious writings in Arabic. ${ }^{24}$ O'Shaughnessy, following Andrae, traces some Quranic verses about Jesus to the Syriac writings of the Aramaean Bishop Aphraates through Babai the Great and the Nestorian Arabs of Hira. ${ }^{25}$ Syriac Christianity was original in its "ascetic and mystical theology", in its "practical rather than speculative theology, illuminating rather than defining the nature of the relationship between the divine and human spheres." ${ }^{26}$ This comment refers to the writings of Aphraates, which were part of the common stock of knowledge in Hira.

The prophet Muhammad had access to the Monophysite Christians of Western Syria while leading trade caravans for Khadija. He was also known to have retired periodically to the caves near Hira to meditate in seclusion. His first revelation was famously received while on one of his trips there. ${ }^{27}$ Hira may be the principle center from which Muhammad may have come across ideas about Jesus, ideas which were

\footnotetext{
${ }^{23}$ W.M. Watt, Muhammad: Prophet and Statesman (London: Oxford University Press, 1961), 6.

${ }^{24}$ Trimingham, 163.

25 Thomas O'Shaughnessy, The Development of the Meaning of Spirit in the Quran (Rome: Biblical Institute Press, 1953), 28. The link between Babai and Muhammad was originally proposed by Tor Andrae.

${ }^{26}$ Trimingham, 133.

${ }^{27}$ Alfred Guillaume, The Life of Muhammad: A Translation of Ibn Ishaq's Sirat Rasul Allah (Karachi, Pakistan: Oxford University Press, 1955), 106.
} 
undoubtedly filtered through the prism of Islamic monotheism during his life and afterwards.

With respect to Jesus, the information available seems to support the idea that the Prophet Muhammad was familiar with some images of him that were predominant in the nominal or non-affiliated region between the Persian and Byzantine states. The Quranic Jesus can be considered a continuation of these regional Christologies in one important respect: the circumstances surrounding his birth and childhood. The annunciation, birth, and childhood of Jesus are all narrated in detail within the Quran. Four descriptions are found in Syriac sources. The Protoevangelium of James has Mary receiving sustenance from an angel; in the Gospel of Pseudo-Matthew, Mary finds repose under a palm tree; in the Arabic infancy Gospel Jesus speaks in the cradle; ${ }^{28}$ and, in the infancy story of Thomas Jesus creates birds from clay, giving them life by breathing into them. ${ }^{29}$ Three of these apocryphal gospels were in Syriac manuscripts before the advent of Islam.

One point worth mentioning is that though we find textual parallels between Jesus in the Quran and Jesus in non-Orthodox Christian communities there is no clear material connection, or documented point of contact, between Muhammad and an actual teacher. It is most likely that he was influenced by various religious communities before his first revelation. Various attempts have been made to trace aspects of Jesus in the Quran to a material source, yet no sustainable narrative emerges. Three different types of sources merit our attention: his formative contacts with such personages as Bahira or Waraqa, the refugee Muslim community in

\footnotetext{
${ }^{28}$ The oldest extant edition post-dates the Quran, and it is possible that the version available to scholars is based on the Quran. See Parrinder, 27.

${ }^{29}$ Neal Robinson, Christ in Islam and Christianity (Albany: SUNY Press, 1991), 19.
} 
Abyssinia, and personal contacts with later converts outside the restricted theater of Meccan paganism (Salman Farisi and Jewish, Khazraj, or Aws tribes in Medina).

In Islam, the stories of the Prophet Muhammad's encounter with the monk Bahira and Khadija's cousin Waraqa are signs that bolster the legitimacy of Muhammad as a prophet. These men were Christians, with knowledge of scripture (particularly prophecies of the final messenger), and they readily recognized Muhammad as the prophet foreshadowed in the Bible. Bahira is recorded to have been interested in Muhammad when he noticed a cloud shading him from the desert heat and the movement of tree branches to do the same. After inviting the caravan Muhammad was travelling with for a meal, and confirming to himself that the boy in the caravan was the prophet foretold in the scriptures he had with him in his hermitage, Bahira confided his discovery to Muhammad's uncle, Abu Talib, and advised him to protect Muhammad from enemies that might try to kill him. ${ }^{30}$ The significant detail in this story is that Bahira recognized the mark of prophecy on the back of the adolescent Muhammad. ${ }^{31}$ When Muhammad reached maturity and eventually began to preach, he was again confirmed in his claims by a Christian — this time Waraqa — with knowledge of the scriptures. Two reports are given: the first that Khadija sent him with a commercial caravan to Syria, before their marriage, and that along the way his traveling companion, Maysara, saw two angels giving shade to Muhammad. $^{32}$ Maysara later told Khadija, who consulted Waraqa, who then confirmed that the time for Biblical prophecies related to the final messenger was near. The second report occurs after the first revelation when Khadija, in an effort to reassure Muhammad that his experiences were not hallucinations, consults Waraqa to

\footnotetext{
${ }^{30}$ Guillaume, $79-81$.

${ }^{31}$ Lings, Muhammad, 30.

${ }^{32}$ Ibid., 82-83.
} 
the same effect. ${ }^{33}$ These stories are preserved in Islamic historiography to demonstrate that the prophetic mission of Muhammad was expected and subsequently verified by men with knowledge.

The stories are also prominent in Christian polemic, but for very different reasons. John of Damascus was the first to mention Bahira as an Arian monk named Sergius. He viewed Bahira - consistent with the mindset of a chronicler of heretical movements - as a Nestorian who taught Muhammad heretical Christianity. From the pen of this influential polemicist emerged the notion, continuously elaborated through the centuries, that Muhammad had acted as an instrument of this disaffected Nestorian to undermine orthodox Christianity. ${ }^{34}$ This idea formed the basis for anti-Muhammad polemic - it was assumed that if Muhammad was sufficiently discredited, his religion would consequently disintegrate. Tor Andrae moderates the radical position of John of Damascus without compromising on the essential idea that in his trips to Syria Muhammad acquired all he would need to know about Christianity. Muhammad's knowledge of Jesus, however much lacking in detail, was transmitted from the teachings of heretical sects.

Muhammad cannot have had permanent personal relations with Christians who had accurate information concerning their religion. What he did learn about Christianity in the course of time... was apparently obtained from persons whose religious knowledge was extremely incomplete. ${ }^{35}$

Muhammad had no first-hand knowledge of the doctrines or institutions of Christianity and Andrae questions whether or not he ever even visited Christian Syria. ${ }^{36}$ Yet, whatever informal contacts he did have with Christians were, according

\footnotetext{
${ }^{33}$ Watt, Muhammad: Prophet and Statesman, 22.

${ }^{34}$ Daniel, 5, 109-110.

${ }^{35}$ Andrae, 125.

${ }^{36}$ Ibid., 48-51, 124-125.
} 
to Andrae, manifest in the Quran in one of two ways. Either he incorporated data and ideas that he agreed with - in the context of his prophetic ministry this means anything that did not compromise the absolute transcendence of God, such as the infancy stories of Jesus or the tales of the seven sleepers of Ephesus, or he rejected them, as is the case with the divinity of Jesus. ${ }^{37}$ We can not make a definite determination about the nature of the exchanges between Muhammad and Bahira or Waraqa. What we do know is that they are legitimizing figures in Islamic historiography. There is no basis to assume that they were created out of thin air, and a moderate view of them can be formulated in terms of their perception that Muhammad, both as an adolescent and in his early twenties, was an extraordinary person whose charisma would have some positive historical impact.

Aside from the negative intent of Christian polemic concerning Bahira there is an important insight to be gleaned from an appreciation of the religious milieu of Arabia during the lifetime of Muhammad. The textual parallels mentioned above are all positive declarations about Jesus. They serve to embellish and substantively support Muslim understandings of Jesus. More importantly, their entry into the stock of knowledge of Muhammad occurred before the first revelation to the Prophet. If we recognize the Nestorian and Monophysite influence on Muhammad's thoughts on Jesus, or if we accept the notion that he was informed, at least in part, about Jesus from Bahira or Waraqa, the most reasonable conclusion that can be reached is that the basis for the Quranic Jesus existed in the mind of Muhammad before 610 C.E. Andrae aptly illustrates the process of cultural adaptation detailed above:

Tradition tells of a Christian preacher who belonged to a tribe living at Hira in Mesopotamia, whom Muhammad is supposed to have heard preaching in the market (no source is recorded). The words fall by the wayside and upon stony ground. But when it finds a receptive spirit its power is often greater than we are able to comprehend. The message

\footnotetext{
${ }^{37}$ Ibid., 123-5.
} 
which Muhammad heard concerning the one God, His goodness, and His judgment, took root in his soul. Many years passed; the outward conditions and the associations in which the message reached him faded from his memory; but the words lived. Unrealized by him, its innermost meaning, the creative energy of its ideas, became Muhammad's personal spiritual possession. It was intensified by what he heard from time to time concerning the Christian hermits and itinerant preachers, who also occasionally passed through Hejaz. And it is part of the mystery of the inspiration of the Prophet and of the poet, that the power which these ideas wielded over his soul was never fully clear to him until, like a revelation from above, they emerged in a new form of unsurmised and incomprehensible clarity and consistency. ${ }^{38}$

Andrae attributes to the prophet Muhammad a unique capacity to learn from his environment and retain even minute details. Two points are important to keep in mind: first, the impressions gathered in his younger life were all filtered through his revelation in accord with the main message of that revelation: the Oneness of God and consequent duties towards Him. Secondly, the "clarity and consistency" of his religious message would later operate in a dialectical relationship with other forms of Christianity.

Neal Robinson has carefully considered the relationship of the Quranic Jesus with the non-Orthodox Christian communities in Mesopotamia and Syria and concluded that the "explanation of the Quranic representation of Jesus exclusively in terms of Nestorian and Monophysite influences is attractive because it is a neat solution to the problem [of the origin of Quranic data on Jesus]. It is, however, almost certainly an oversimplification." ${ }^{39}$ The prophet had a clear idea about Jesus which cannot be understood as haphazard borrowings from various unnamed 'sources', but is in line with the point made by Andrae that these influences "took root in his soul" and "became Muhammad's personal spiritual possession."

\footnotetext{
${ }^{38}$ Andrae, 126-7.

${ }^{39}$ Robinson, 20.
} 
There is less substantial information about the exchange of information between the Prophet and Christian Abyssinia via the group of refugees he sent there as Meccan repression of Muslims intensified. ${ }^{40}$ Andrae suggests that the notion of the trinity consisting of God, Jesus, and Mary (which is denied in the Quran) came from Abyssinia $^{41}$ but there are no other detailed exchanges. We know for certain, from the Sirat Rasul Allah of Ibn Ishāq, that the emigrants introduced the teachings of Islam to the Negus (the ruler of Abyssinia) with verses about Jesus from surah Maryam (19:133). ${ }^{42}$ This surah details the annunciation, conception and birth of Jesus; in it Jesus describes himself as a prophet obedient to God, and there is a qualifying verse relating to the virgin birth — "He (God) says 'be' and it becomes"— and sonship. Then, when the Meccan delegation secretly planned to discredit the Muslims by informing the Negus that Jesus is merely human in the Quran, one of the emigrants responds, confirming this fact, and recites verse $4: 171:^{43}$

O people of the Book, do not exceed the bounds of your religion, nor say about Allah except the truth. The Messiah, Jesus, Son of Mary, is only Allah's Messenger and His Word, which he imparted to Mary, and is a spirit from Him...do not say "three" (gods). Refrain; it is better for you. Allah is truly One God... To Him belongs what is in the heavens and on earth.

Though Abyssinia was a center of Monophysite Christianity it is clear that the main ideas of the Quranic Jesus already existed. O'Shaughnessy ${ }^{44}$ dates this verse to the later Medinan period, when contacts with Christians would have created the

\footnotetext{
${ }^{40}$ Watt, Muhammad at Mecca (Oxford: Clarendon Press, 1953), 110-116. Watt also gives some other possible reasons for the emigration but none are supported by his sources and he relies too heavily on extrapolating from irrelevant facts and forcing an interpretation on them. For example, if the Prophet intended trade or politics with Abyssinia it would have manifested after his emigration to Medina. The fact that Muhammad did not pursue these policies aggressively after his move to Medina all but disqualifies trade or politics as explanations for the emigration to Abyssinia.

${ }^{41}$ Andrae, 125.

${ }^{42}$ Guillaume, 152-3.

${ }^{43}$ Goddard, 21.

${ }^{44}$ O'Shaughnessy, The Development of the Meaning of Spirit in the Quran, 15.
} 
conditions for the revelation of verses critical of Christian attitudes. This is an acceptable interpretation considering the fact that verse 4:171 has a recognizable audience which Muhammad most likely met in Medina as he was rising to political prominence in the region. But the response was a considered decision by the emigrants to "say what God had said and what the Prophet had brought." ${ }^{45}$ The response already lays out the basic ideas behind the Quranic vision of Jesus, mentioning him as a servant of God, His word and spirit, born of a Virgin mother.

Some Christians from Abyssinia were impressed by what they heard about Muhammad and his message and went to visit him in Mecca. After questioning Muhammad and listening to the Quran they embraced Islam. There was no discussion about Jesus in the Sirah account. ${ }^{46}$ It seems as though they were sufficiently impressed by the personality and message of Muhammad to have not pressed the issue. Abu Jahl, a prominent opponent and kinsman of Muhammad in Mecca, accosted this group sarcastically: "what a wretched band you are! Your people at home sent you to bring them information about the fellow, and as soon as you sat with him you renounced your religion and believed what he said. We don't know a more asinine band than you." ${ }^{47}$ While in Mecca Muhammad had supreme confidence in the authenticity and universal validity of his message. This attitude was tested daily by the elites of the city; it was later debated among a group of sixty Christians from Najran. There were disagreements about Jesus and during their discussion the beginning verses from surah al-Imran were revealed (up to eighty verses), which

\footnotetext{
${ }^{45}$ Guillaume. 152.

${ }^{46}$ Guillaume. 179.

${ }^{47}$ Guillaume. 179.
} 
include the story of Zachariah and Jesus. ${ }^{48}$ This reiterates the main contours of the Quranic Jesus as part of the early revealed verses.

One interesting detail in the above exchange is that there is no change in the ideas propounded by the prophet. The passages are a retelling of the story of Zechariah and the infancy of Jesus. At no time during the twenty-three year mission of Muhammad does he enter into detailed dialogue on Christological issues. The exceptions to this are the repeated denials of divine paternity and verses 5:116-8. The effect and extent of later contacts with Abyssinian emigrants or Medinan converts like Salman from Persia on the Islamic Christology are minimal. ${ }^{49}$

The debate that demonstrates the lack of direct exchange between Muhammad and Near Eastern Christians is known as the mubahalah, or "invocation of God's curse, ${ }^{50}$ and it occurs early in Medina:

To who dispute with it after the knowledge which has come to you, say "come now; let us call our sons and your sons, our wives and your wives, ourselves and yourselves. Then let us pray to Allah and so call down Allah's curse upon the liars."

Ibn Ishâaq places this encounter before the battle of Badr. It seems improbable that political or military considerations were a factor in the outcome of this debate. ${ }^{51}$ The deputation from Najran declined the offer of invoking God's curse in favor of mutual autonomy with respect to the person of Jesus. ${ }^{52}$ This encounter is not a debate on

\footnotetext{
${ }^{48}$ Guillaume, 270-2. Noldeke and other western Islamicists date these verses to the late Medinan period. See Richard Bell, Introduction to the Quran, 108-114.

${ }^{49}$ The only new idea to appear in the Medina period is the use of the descriptive adjective qudus with Gabriel in connection with his interaction with Jesus. Gabriel is identified as the agent of revelation between God and His messengers in the early Medina period. He is also identified at the Holy Spirit, ruh al-qudus in the later Meccan period (16:104).

${ }^{50} 3: 61$.

${ }^{51}$ Ayoub, 20, seems to think that the Christian side was worried about stable diplomatic relations with Muhammad and declined, on that basis alone, the mubahalah.
} 
Christology between the prophet and the Christian delegation. From the Quranic verses, the historical context, and the narrative of the mubahalah in Ibn Ishaq's biography it is clear that this debate was about authority in religious discourse. The prophet was uncompromising in affirming his status as messenger; otherwise he would have lost credibility among his followers, and the disbelievers or hypocrites were only too willing to capitalize on any sign of weakness from him. Instead of debating about the nature of Jesus, the prophet Muhammad assumes superior authority and recites Quranic verses contrasting the human Jesus with the transcendent God. The subject of disagreement is Jesus' divinity, and the final word to the Christians is to "come to a just word common between us and you: that we worship none other than God, that we associate nothing with Him, and that we do not take one another as lords instead of God" (3:64).

Scholars have attempted to reconstruct the chronology of the individual verses using primary documents such as the early biographies of Muhammad and hadith literature. With respect to Jesus this approach yields little or no positive results. The earliest Meccan verses clearly delineate the Quranic conception of Jesus. Parrinder and Robinson, both building upon the work of Noldeke, place the majority of Quranic verses about Jesus in the Medina period. The assumption here is that the Prophet would have had more contacts with Monophysite Christianity while in Medina. But the essential narrative and key concepts relating to Jesus - with the exception of his being aided by Gabriel — appear in the Meccan verses. The basic ideas found in the Quran represent what Ismail al-Faruqi referred to as the Semitic Spring of Consciousness. ${ }^{53}$ This includes Syriac and Hebrew ideas which are all related by a

\footnotetext{
${ }^{52}$ Guillaume, 277. The reason given by the classical biographers is that their leaders recognized Muhammad as a legitimate prophet and were fearful that God would decide in his favor by bringing an end to their community.

${ }^{53}$ Ismail Ragi Al-Faruqi, Islam and Other Faiths (Leicester, UK: The Islamic Foundation, 1998).
} 
relatively common history, language, and mode of being. Instead of trying to build theories about possible sources for the Quranic verses it may be more profitable to think in terms of broader themes represented in the religious texts coming out of this region. 


\section{Chapter II: On the question of ad hoc revelations.}

A subtle distinction needs to be made between types of borrowing, or historical cross-fertilization, and the manner in which they can be explained. The first type of adaptation is conditioned by the religious environment of the Prophet from his first trips into Syria during his childhood through the start of his prophetic ministry. The textual parallels lead us to conclude that any of the information that could have been known to Muhammad came before his first revelation at the age of forty. And the consensus interpretation is that any exchange of ideas occurred only orally and informally. ${ }^{54}$ This could only take place before he claimed to receive the first revelation. Afterwards, he resided exclusively in Mecca and Medina. His only travel outside these cities during the last twenty-three years of his life was an unsuccessful attempt to find patronage after the death of Abu Talib in $619 \mathrm{CE}^{55}$

The second view contends that the process of adaptation occurred regularly after his first revelation and in response to political events. ${ }^{56}$ This interpretive paradigm has been used primarily to deal with the evolution of Muhammad's religious thought vis-à-vis the Jewish tribes of Medina. Jacques Waardenburg has outlined this approach nicely: Muhammad knew of Judeo-Christian teachings on God, prophets, and scriptures. He located himself within this tradition and freely borrowed ritual prescriptions (Friday for congregational prayer and Jerusalem as the qibla) and biblical stories to fill in the content of his message. ${ }^{57}$ After being forced to look for asylum outside of Mecca in $619 \mathrm{CE}$, he was invited to Medina by the Aws and Khazraj tribes. For Waardenburg, Muhammad had high hopes of being accepted as a

\footnotetext{
${ }^{54}$ R obinson, 17.

${ }^{55}$ Watt. Muhammad, Prophet and Statesman, 79.

${ }^{56}$ See O’Shaughnessy and Jacques Waardenburg Muslim Perceptions of Other Religions: A Historical Survey (New York: Oxford University Press, 1999).

${ }^{57}$ Waardenburg, 11.
} 
prophet by the Jewish community of Medina - this is a major assumption on his part and is not supported by even a cursory reading of the life of Muhammad - but that after being rejected by them changed the ritual orientation of his religion (making the Ka aba in Mecca the direction of prayer) and re-conceptualizing himself and Islamic monotheism in the image of Abraham. ${ }^{58}$ What is striking in this case is that the content of Islam is assumed to be determined by political disagreements. It is valid to argue that the Quranic criticism of Judaism and Christianity are occasioned (the sabab al-nuzul or reason of revelation) by political contacts - this is an approach common to both Western and Islamic scholarship. But Waardenburg, as had Muir before him, ${ }^{59}$ makes the mistake of identifying the religious beliefs with the political position of Muhammad, without appreciating their contrasting qualities.

The Prophet's conflict with Jewish tribes in Medina was not occasioned by their refusal to embrace his religion, but because of political and economic considerations. ${ }^{60}$ Watt makes the point that the Jewish tribes of Medina had traditionally had a privileged position in Medina, a position which the Prophet and his followers compromised. They willingly entered into a political agreement with Muhammad because, until the battle of Badr, they judged him and his followers to be weak. $^{61}$ As the situation of the immigrant community in Medina strengthened economically, politically, and militarily these previously privileged tribes began to

\footnotetext{
${ }^{58}$ Ibid, 12.

${ }^{59}$ Irving M. Zeitlin, The Historical Muhammad (Polity Press, 2007), 126-7.

${ }^{60}$ Watt. Muhammad: Prophet and Statesman, 93-101. Muhammad made political harmony between himself and the Jewish tribes of Medina preeminent over religious considerations. Also, see M.S. Kister- in The Arabs and Arabia on the Eve of Islam, 146-8- on the pre-Hijrah political power struggles in Medina between the Aws and Khazraj tribes and the Jewish communities. Their legitimacy to rule was tied to patronage from Hira. With the decline in Hiran hegemony there were no institutions in place to collect taxes or maintain order, resulting in inter-tribal warfare- from which the Jewish tribes benefited- and leading to the invitation to Muhammad to live in Medina as arbiter and first citizen.

${ }^{61}$ Watt, 192-204.
} 
conspire against Muhammad, ultimately joining the Meccan invaders at the Battle of the Trench.

There are no grounds for assuming that Muhammad tailored his message to satisfy the predilections of those whom he wished to convert to Islam. It is true however, that the Prophet would occasionally adopt a practice from Jews or Christians if there were no specific divine directive on an issue. ${ }^{62}$ But, the excess in historical interpretation is clearly demonstrated in the conclusion to the above narrative that the universalism of Islam was developed in opposition to Jewish particularism. ${ }^{63}$ Fazlur Rahman aptly describes this theoretical paradigm:

The classic formulation of a view of the emergence of the Muslim community in Medina as a separate entity from the Jewish and Christian communities seems to have become a permanent part of the patriarchal legacy for many Western Islamicists. The theory invites us to accept (1) that in Mecca, the Prophet was convinced that he was giving the same teachings to the Arabs which earlier Prophets had given to their respective communities, (2) that when, in Medina, Jews and Christians refused to accept him as Prophet, he began appealing to the image of Abraham whom he disassociated from Judaism and Christianity, claiming him exclusively for Islam and linking his community directly with him. Further elaborations of the theory depict this development as a major, indeed, basic diversion from the Prophet's original stance, culminating in the "nationalization" or "Arabization" of Islam." 64

The major assumption here is that Muhammad was to a great degree dependent on Jewish and Christian communities for his own legitimacy. Frustrated by their rejections of his claim to be the final Prophet, he lashed out against them and in turn rejected their traditions as falsified, as well as castigating them through the Quran. The question arises: do the distinctions between Islam and other Abrahamic faiths developed in the Quran represent the natural differences between Muhammad's

\footnotetext{
${ }^{62}$ Marston Speight, 'Christians in the Hadith literature,' in Islamic Interpretations of Christianity, ed. Lloyd Ridgeon (New York: St. Martin's Press, 2001), 32.

${ }^{63}$ Watt, 192-204.

${ }^{64}$ F.E. Peters, The Arabs and Arabia on the Eve of Islam (Ashgate Publishing Limited, 1999) 185-6.
} 
monotheism and groups he encountered? Or are the Quranic criticisms of Judaism and Christianity - a topic of study in and of itself - a product of their rejection of the legitimacy of Muhammad? If Monophysite Christians from Najran accepted Muhammad as prophet and political leader would he have reacted favorably by adopting their Christology? If the Jewish tribes in Medina accepted Muhammad would he have produced verses praising them and the tribes of Israel?

My view is that Muhammad was from the start an institution unto himself, meaning, he was the final authority on religious matters. During his twenty-three year ministry disputes and unanswered questions were definitively arbitrated by Quranic revelations. From the account of the Prophet's meeting with the Christian delegation from Najran ${ }^{65}$ he was insistent on his own Christology and was anything but conciliatory with respect to the divinity of Jesus and the symbolism of the cross. Muhammad had already identified himself as a Messenger in the Judeo-Christian tradition while in Mecca. His Night Journey_ "Glory be to Him Who caused His servant to travel by night from the Sacred Mosque to the Farthest Mosque, whose precincts We have blessed, in order to show him some of Our Signs" (17:1) — is the first major event during his Prophetic ministry which links his religious experience to the Biblical prophets.

This event had a more formative influence on the religious message and self perception of Muhammad than later relations with Jewish and Christian communities. The connection between the prophet and earlier Jewish and Christian communities (as well as the prophets of the Old Testament and Jesus) clearly dates from the early Meccan period. This also applies to the importance of Jerusalem. The date at which the prophet began to identify himself with these predecessors corresponds exactly to

\footnotetext{
${ }^{65}$ Guillaume, 272 and Goddard, 22.
} 
the night time ascension recounted in 17:1 and the hadith. ${ }^{66}$ Irrespective of whether one regards the story as real or symbolic it is important because it establishes the use of Jewish and Christian material, a direct and emotional identification on the part of the prophet, prior to intimate contacts with such communities in Medina. According to Bell, the appearance of stories of earlier prophets and the punishment which befell the disbelieving communities coincides with the institutionalization of the prayers, which is explained by the night time ascent. ${ }^{67}$

There certainly were contacts between Muhammad and the people of the book - Jews and Christians; according to Richard Bell, the fact that there was no preIslamic translation of the Bible in Arabic nor usage of Arabic in church services in Arabia indicate for Bell that the Prophet's sources were either Jewish tribes or Jewish Christians. ${ }^{68}$ While Bell deals with the concrete relationship between the Prophet and the religious environment of Arabia he ultimately recognizes that Muhammad codifies a completely new religious vision by synthesizing known data with his personal religious experience - independent of consultation. A lengthy quote is in order:

[there was] considerable originality in Muhammad, not the originality which produces something absolutely new, but the originality of a strong mind, working upon very imperfect information of outside things, yet finding expression for ideas and aspirations which were dimly present in other minds. He claimed to be an Arab Prophet, and he was. We shall see him consciously borrowing - he is quite frank about it. But to begin with, the material which he uses, though they may remind us ever again of Jewish and Christian phrases and ideas, are in reality Arab materials. They may have been originally derived from outside Arabia, but they had by Muhammad's time become part of the Arab mind... As regards Christianity, his own direct knowledge of it was to begin with... just such knowledge as we might expect in a caravan trader who had been to Syria and seen Christian churches, and perhaps Christian services. ${ }^{69}$

\footnotetext{
${ }^{66}$ Saḥịh al-Bukhārī, trans. Muhammad Muhsin Khan (Medina: Dar Ahya us-Sunnah, n.d.), 211-214.

${ }^{67}$ Bell, 137-8.

${ }^{68}$ Zeitlin, 96.

${ }^{69}$ Zeitlin, 97. (This is a point contradicting the view of Andrae)
} 
The narrative of Waardenburg and like-minded scholars ${ }^{70}$ invariably oversimplifies the historical record. The reason being that they impose upon the texts at their disposal an evolutionary narrative that credits Jewish and Christian communities - in exclusively negative ways - with having determined the intellectual and spiritual content of the Prophet's message. In this way the ad hoc revelations are contextualized in terms of the evolution of the religious message of Muhammad, when, in fact, a proper understanding of them should be in relation to concrete socio-political relations - the Quran is commenting on existing realities rather than being shaped by them. Conversely, the essential religious message of the Prophet - the transcendent unity of God, mankind's relation to Him, and eschatological warnings - come to be understood as unintended distortions of sermons he might have heard from people who might have existed. ${ }^{71}$ But the religious message, the content of the revelations preached by Muhammad, has a remarkable internal consistency from the early, shorter surahs through the Medina period where the revelations become progressively more discursive and related to concrete incidents.

Fazlur Rahman deals with the implications of the critical historical approach in apologetic terms: "Muhammad insisted... that they were revealed to him. He was, of course, right. For, under the impact of his direct religious experience, these stories became revelations and no longer remained mere tales as they were before." ${ }^{72}$ Instrumental in this process of appropriation was the connection between Muhammad and other Biblical and non-Biblical prophets. The prophets were his predecessors, teaching essentially the same message; they were also a source of legitimacy for him.

\footnotetext{
${ }^{70}$ F.E. Peters, Muhammad and the Origins of Islam (Albany: SUNY Press, 1994), 198-210.

${ }^{71}$ O'Shaughnessy, The Development of the Meaning of Spirit in the Quran, 53.

${ }^{72}$ Fazlur Rahman, in Peters, The Arabs and Arabia on the Eve of Islam, 195.
} 
The prophets formed a fraternity that upheld the same essential truths and, either by prophecy or confirmation bore witness to one another. The experience of receiving revelation united these disparate historical figures, and it is on this basis that Muhammad upheld "the identity of the messages of all Prophets. All scriptures stem from and are part of a single source, the Heavenly Archetype called The Mother of Books and also The Hidden Book" so that "just as Muhammad follows upon and inherits the missions of earlier Prophets and the Quran receives the legacy of earlier Revelations, so does the Muslim community now inherit the place of earlier communities. ${ }^{73}$ In this there is continuity with the past as well as discontinuity with anything that does not fit into the Quranic framework. The Quranic portrait of God's messengers is continuous from Adam until Muhammad. Any discrepancy in the Prophetic narrative is attributed to earlier communities- $2: 75 ; 4: 44,51-55 ; 5: 12-$ 14 - for having been incapable or unworthy stewards of divine revelation. Nowhere in the Quran is it suggested that the original revelations vouchsafed to earlier prophets exist exactly as they were sent down.

This concludes my inquiry into the status of Jesus in Islam as independent. It was necessary to look at the possible influences on the Prophet's view of Jesus and obvious divergences. We have seen that Christian communities held certain ideas later found in the Quran such as infancy tales and the creation of birds from clay. Yet, the major doctrines of Christianity, whether orthodox or heretical, were not carried over into the Quran. The Quran is clearly dismissive of the incarnation, trinity, and salvation theology. Though the Christianity of Arabia was not orthodox in the Byzantine tradition - Watt suggests that the Prophet was not even well informed on

\footnotetext{
${ }^{73}$ Ibid. 195
} 
the heretical varieties of Christianity $-{ }^{74}$ the basic position of Islam formulated during the life of the Prophet does not seek to reform heretical Christologies, but branches out in an independent direction.

74 William Montgomery Watt. Muslim-Christian Encounters: Perceptions and Misperceptions (London: Routledge, 1991), 25. 


\section{Chapter III: Orienting the Islamic discourse with consideration of its product as}

\section{independent}

Quranic passages that deal with Jesus are not as thorough or clearly delineated as representations of other prophets - consider Moses and the surah dedicated to the story of Joseph. Often, the Quran represents Jesus in contra-distinction to general Christian images. The Quranic Jesus is essentially a skeletal image of a seminal messenger in the Islamic narrative of prophecy. There are certain key characteristics which we find numerous times. From customary titles for Jesus, denials of divine status, infancy stories, and stories about Jesus' interaction with his disciples and others. Two critical points should be made about Jesus in Islam. First, Islamic Christology is a self-contained discourse that relies on the standard sources available to Muslim scholars to define who Jesus is in the Islamic tradition. As such Islam does not admit a Christian reading of the Quranic Jesus. ${ }^{75}$ Secondly, as a consequence of the skeletal conception of Jesus within the Quran, Muslim thinkers have the unique opportunity of commenting or elaborating upon unclear aspects of Jesus from a perspective based on the fundamentals of Islamic thought. This can be a new dialogue within Islam using primary and secondary texts. But it must be recognized that Christian scholars are legitimately interested in what the Quran and Muslims have to say about Jesus.

Traditionally, Muslim approaches to Jesus have predominated in polemical discourses, wherein theological distinctions are introduced and positions argued (see chapter 5$).{ }^{76} \mathrm{He}$ is also widely discussed among the Sufis and other practitioners of

\footnotetext{
${ }^{75}$ R.C. Zaehner, At Sundry Times (London: Faber and Faber, 1958).

${ }^{76}$ See A.D. Ajijola The Myth of the Cross (Delhi: Rightway Publications, 2002); Muhammad Ata urRahman, Jesus: Prophet of Islam (Elmhurst, New York: Tahrike Tarsile Quran Inc., 1991); Jay Crook, The Bible: An Islamic Perspective, Jesus (Chicago, Illinois: ABC International Group, 2005); Faruqi, Christian Ethics; Jean-Marie Gaudeul, Encounters \& Clashes: Islam and Christianity in History, 2 vols. (Rome: Pontificio Istituto di Studi Arabi e Islamici, 1984); Goddard, A History of Christian-
} 
the mystical life. ${ }^{77}$ In the contemporary period there have been pious, sympathetic biographies written about Jesus by intellectuals like Kamel M. Hussein and Abbas Mahmoud al-Aqqad. ${ }^{78}$ An influential series of articles attempting to develop a systematic image of Jesus in Islam was written by Mahmoud Ayoub. ${ }^{79}$ There are also Christian scholars who, in reading the Quranic portrayal of Jesus, see an image of their own Christ, whom they love, worship, and accept as savior. There is a tendency among learned Christians to try to bring the Christologies of Christianity and Islam into closer harmony than just a shared recognition of the unique role of Jesus in history. There are a few reasons for this. The first can naturally be assumed to be the desire to rescue Christian views of Jesus from Islamic portrayals that deny him his traditional role as savior and subordinate his importance to the prophetic career of Muhammad. Another, arising out of missionary endeavors, is to bring communities together through sympathetic or syncretistic readings of other scriptures.

The approach to the Quran and the Islamic Jesus that I want to address in this section is surely syncretistic, subtly or overtly polemical, but also historical. It is an interpretatio christiana. ${ }^{80}$ It is a method of interpretation which seeks to minimize the differences between Christian and Islamic Christologies by 'sourcing' the Christology of the Quran to Near Eastern Christian communities and selected individuals, thereby

\footnotetext{
Muslim Relations; and Maulana Muhammad Ali, Muhammad and Christ (Lahore: Ahmadiyya Anjuman, 1993).

${ }^{77}$ Khalidi, The Muslim Jesus; Javad Nurbakhsh, Jesus in the Eyes of the Sufis (London: KhaniqahiNimatullahi Publications, 1983); James Robson, Christ in Islam (California: Bardic Press, 2006); James Roy King, "Jesus and Joseph in Rumi’s Mathnawi," Muslim World 80, no. 2 (1990); 81-95; and Ibn al-Arabi, The Bezels of Wisdom, trans. R.W.J. Austin (New Jersey: Paulist Press, 1980).

${ }^{78}$ Kamel Hussein, City of Wrong trans. Kenneth Cragg (Oxford: Oneworld Press, 1994); and Peter Ford, The Genius of Christ, translation of Abbas Mahmoud al-Aqqad's Hayat al-Masih (Binghamton, New York: Institute of Global Cultural Studies (IGCS), Binghamton University, 2001).

${ }^{79}$ Mahmoud Ayoub "Towards an Islamic Christology: An Image of Jesus in early Shia Muslim Literature," Muslim World 66 (1976): 163-188; and, "Towards an Islamic Christology II: The Death of Jesus, Reality or Delusion," Muslim World 70 (1980): 91-121.

${ }^{80}$ Oddbjorn Leirvik, Images of Jesus Christ in Islam (Studia Missionalia Upsaliensia, 1999), 27.
} 
unsettling the absolute religious claims made by the Quran. It was dealt with above on two levels. First, I dealt explicitly with the documented evidence and textual parallels, most of which are not found in the canonical Gospels. It was noted that the opportunity for Muhammad to come across this information occurs only before he first had his revelations in Hira. They form much of what is recognized as information revealed in Mecca. The verses about Jesus that were revealed in Medina deal more explicitly with controversial issues and represent a negative Christology. Both of these aspects of the Quranic portrayal of Jesus were later taken up and expounded by Muslim authors.

Yet, on the issue of Jesus, the context, or reasons for which the revelations were sent down, is not so much an issue for Islamic scholars (who had devised this category in the first place, and used it frequently in interpreting the Quran) as it is for Christians. Essentially, Muslim approaches to Jesus deal with the substance of Quranic data in order to derive some kind of benefit or guidance from him. This applies equally to all other prophets mentioned in the Quran because there is no difference between messengers, just the role assigned to them. An interpretatio christiana has different aims in mind, namely syncretism. The foundation upon which Christian attempts at syncretism are made is a certain reading of the historical record. In the discussion of ad hoc revelations it was noted how a developmental scheme in understanding the formation of the Quran serves to subtly undermine the internal coherence of the text and completely disparage the veracity of the prophet Muhammad. For example, the reorientation of the Qibla from Jerusalem to Mecca is viewed as a result of religious disagreements with Medinan Jews, rather than of basic religious questions such as the symbolic center of the earth (axis mundi) or the link 
with the historical Abraham and Ishmael (the original builders of the Ka`aba). ${ }^{81}$ But, in the mind of syncretistic writers, if Muhammad is extemporaneously authoring his religion with respect to Medinan Jewry, it must follow that he engaged in the same practice with respect to Christianity and Jesus. This is the fundamental premise of positivist historicism, upon which an interpretatio christiana is based.

R.C. Zaehner gives a very concise and explicit Christian interpretation of the Quranic Christology. He tries to demonstrate that far from denying the divinity of Jesus, his sonship, the crucifixion, and resurrection, the Quran can be read to confirm these dogmas. And on that basis Zaehner is willing to accept Muhammad as a prophet in the Hebrew tradition. ${ }^{82}$ He begins by quoting the verse $(4: 171)$ which identifies Jesus as a Word and a spirit from God. For Zaehner Muhammad had adopted the terminological usage of kalima (word) and ruh (spirit) from an unidentified Christian source or sources. And he had misapprehended his sources to boot. ${ }^{83}$

What, in fact, is Muhammad denying in this passage? Nothing more, it would appear, than that God was physically the Father of Jesus. Muhammad, though he certainly knew of the Christological controversies that had been raging during the last centuries, was not a trained Christian theologian, and for anyone who was not just that, the whole concept of the 'generation' of the Word must either have been incomprehensible or implied that God had taken on a human form and cohabited with Mary rather as the ancient gods did in pagan legend. Such an idea was rightly abhorrent to the Prophet. In this passage he in fact affirms not only the Virgin Birth on which the Quran always lays great emphasis, but also that Christ is 'only' God's messenger and His Word (kalima) - a spirit from Him, that is to say, not carnally conceived, but conceived by the divine afflatus and the divine fiatexactly, then, what orthodox Christianity means by 'Word made flesh'. $^{84}$

\footnotetext{
${ }^{81}$ Peters, 207-210; and, Waardenburg, 11-16.

${ }^{82}$ Zaehner, 195-200.

${ }^{83}$ Zaehner, 201.

${ }^{84}$ Zaehner, 201. Emphasis added.
} 
He goes on to argue that the Quranic denial of the sonship of Jesus is really just a misunderstanding by Muslims of the passage (19:35) which reads: "It is not for God to take to Himself a son." Of course God would not take to Himself a son, Zaehner argues. Jesus does not become divine in time, the way a son would. That is none other than the Arian heresy. Rather Jesus is divine from time immemorial; he is co-eternal with God. According to Zaehner the Quranic denial of Jesus' sonship as having occurred in time is actually a confirmation of his eternally divine status! ${ }^{85}$ What he does not include in this reading is the verse of the Quran that rejects the view that Jesus was with God before creation— (23:91) "there was none with Him."

Zaehner assumes from the outset that the Quranic reference to Jesus as kalima (word) and spirit from God means, per a Christian reading, that Jesus shares in divinity and is co-eternal with God. He makes the argument that Muhammad misunderstood the sonship of Jesus in exclusively physical terms; i.e., Muhammad was under the notion that the Christian doctrine was that God had manifested Himself physically in order to physically inseminate Mary with Jesus. ${ }^{86}$ Muhammad would naturally deny such pagan ideas, but Zaehner is clear that it is the pagan notions rather than Christian ideas that Muhammad is denying. He then very briefly passes over the Quranic references to Jesus as a prophet, messenger, and servant of God in order to launch into his interpretation of the Quranic Jesus as divine, and worthy of worship.

The premise upon which he will base this argument is the comparability of Jesus with Adam. In the creation story, (15:26-30; $7: 11 ; 2: 30-34)$ God orders the angels to prostrate themselves before Adam. Zaehner takes this to mean that Adam was divine but that his divine status was revoked through sin, a Christian apologia. For him Muhammad is "no doubt, unconsciously reproducing the Christian doctrine

\footnotetext{
${ }^{85}$ Zaehner, 202-3.

${ }^{86}$ Zaehner, 203-4.
} 
of Jesus as the second Adam. ${ }^{87}$ It would therefore follow that Jesus, who was sinless and presumably on that account raised by God unto Himself, was also worthy of worship from the moment that God breathed His spirit upon Mary, just as Adam was before Him." ${ }^{88}$ Zaehner is careful to address the repeated Quranic denials of divine paternity as only a rejection of physical insemination by God Himself. In order for him to impose his interpretation on the text he must address every Quranic denial of sonship as a bleak reference to some pagan controversy, rather than Christian doctrine.

Zaehner concludes by reading into the Quran a Nestorian Christology whereby Jesus is both divine and human. He wants to identify the title kalima (word) with the creative command of God, Logos. His rationalization for interpreting kalima in the sense of Logos is that the Quran uses kalima in three related instances: the first creation of Adam, and then of Jesus, and in the resurrection. He also reads the phrase qawl al-haqq in verse 19:34 as 'the word of truth' rather than the more appropriate rendering 'statement of truth'. The former sense allows Zaehner to link Jesus as 'word of truth' with the imperative kun, 'be', in the clause kun fa yakun, 'be and it is. ${ }^{.89}$ On this basis he identifies Jesus as the creative principle because the word kun (be) is assumed to be the creative principle, rather than the speaker of kun, which is God.

Zaehner's interpretatio christiana concludes thus:

Christ, then, in the Quran, would appear to be both the Word of God and therefore divine, and truly man; but He is not the 'son' of God for reasons we have already explained. He is both God-Word and man bila-kayf (without inquiring further as to how this can be)... Muslims, of course, agree in denying the divinity of Christ; but this is the result not of a close and impartial study of the Quran but of an anti-Christian tradition that can already be discerned in the later suras of the Quran itself.

\footnotetext{
${ }^{87}(2: 117 ; 3: 59)$

${ }^{88}$ Zaehner, 206.

${ }^{89}$ Ibid, 206-8.
} 
Further,

The Quran, then, as opposed to traditional Muslim orthodoxy, does not explicitly deny any specific Christian doctrine except that Christ is the son of God and this for obvious reasons that have already been pointed out. For, except to those well coached in Christian theology, sonship implies physical procreation and this is unthinkable in God who is a pure spirit... So far as his Christology is concerned, Muhammad, in the Quran, nowhere denies and sometimes affirms specifically Christian beliefs... he adds nothing new to what had been previously revealed. ${ }^{90}$

This interpretation should be dealt with in respect to the overall Quranic Christology, and with Zaehner's apprehension of the historical Muhammad.

On the scriptural-theological level it is obvious that Zaehner has a perverted and embarrassingly deficient understanding of the Quranic-Islamic weltanschauung, not to mention the methods of interpretation of the Quran, a subject he mentions in passing as a dysfunctional discourse. ${ }^{91}$ What Zaehner fails to see is that Jesus is wholly different in the Quran and in Christian theology. The Quran reiterates ad nausea the humanity of Jesus, the fact that he is a part of creation and limited by that contingent status. Moreover, Jesus is attributed with honorific titles which are at best left ambiguous because they are not explicitly dealt with in the text. For example, he is called al-Masih without further explanation. The faithful Christian already assumes the divinity of Jesus and so in reading the Quranic description of him as spirit from God and His word will feel justified, as Zaehner is, in seeing this as an affirmation of divinity.

But, in order to come to such a conclusion Zaehner has to ignore or explain away a major portion of the Quranic portrayal of Jesus. The verses that are conspicuously absent from Zaehner's appendix speak of the human Jesus who was a

\footnotetext{
${ }^{90}$ Zaehner, 209, 216.

${ }^{91}$ Zaehner, 209-211.
} 
prophet and servant of God, whose birth and childhood are exceptional, and who had a mission to the people of Israel to reform their "legalistic externalization of religion." ${ }^{92}$ Moreover, Zaehner is too liberal in attributing divinity to Jesus, the amr (command) of God, and the spirit (ruh). ${ }^{93}$ He does not consider the Quranic discourse, or the general Islamic discussion of transcendence and the Oneness of God. This inability to understand the most basic Islamic doctrine is perhaps more inexcusable than his reading of the Quranic Jesus as divine. For, while the Quran is adamant about Jesus' humanity and servitude towards God, it does identify him as a spirit from God. Yet, this is common to humanity and nowhere in the Quran is the spirit said to share in the divinity of God, nor is it co-eternal with Him.

The reason Zaehner freely ascribes divinity to the Quranic Jesus is because the historical premise that the Christology of the Quran is borrowed directly from Near Eastern Christian communities. In essence, if Muhammad had encountered certain ideas about Jesus then the process of transmission (of how these images enter into the stream of revelation) happens passively. Per Bell and Andrae, the images and ideas he may have seen are stored in the unconscious until he has his encounter with Gabriel. But Zaehner uses an approach common to Waardenburg, Peters, and O'Shaughnessy which views the collected verses on a given topic as disjointed, incoherent, and absolutely dependent on source material. It follows that if the source material for the Quranic verses related to Jesus is Christian, then the meaning of those verses must carry over from a Christian context. Implicit here is a denial that Muhammad is giving new or different meanings to the ideas he is said to be borrowing. He only borrows haphazardly and without understanding the material he is said to be plagiarizing. ${ }^{94}$

\footnotetext{
${ }^{92}$ Gaudeul, vol. 2: 138.

${ }^{93}$ Zaehner, 214.

${ }^{94}$ Zaehner, 201.
} 
More careful scholars will credit the prophet with refashioning his borrowed material to appeal to potential converts. ${ }^{95}$

These writers do not credit Muhammad with a unified vision of the world or even of his own message. The guiding principle in their individual narratives is that Muhammad's message is articulated in response to external criticism rather than internal-revelational stimuli. Muhammad's claim to prophethood is denied on the implicit methodological premise that the historian or Islamicist cannot confirm that claim and that the subject must be studied clinically. Therefore, any study of the content of his message must be traced to some source. Moreover, Muhammad is assumed to be consciously formulating his message in order to curry favor with Christians whom he wished to convert, though the context of the overwhelming majority of verses is decidedly and exclusively pagan, and a Christian audience is identified in only exceptional circumstances. ${ }^{96}$ In his study of the use of spirit in the Quran Thomas O'Shaughnessy epitomized this scholarly trend. His method is based on using the classical sources and a linguistic analysis of the Quran to identify the development of the use of spirit.

Though the skills he brings to bear on his task represent the highest form of academic proficiency, O'Shaughnessy is immediately and everywhere compromised by the research aim of his work. He traces the development of the use of spirit (ruh) in the Quran but does not deal with the obvious fact that the major uses of spirit all appear early in the prophet's ministry in Mecca. ${ }^{97}$ In the early surahs the spirit is identified as a servant of God and agent of His will, substance used to animate human life, specifically an agent of revelation, and assistant to the faithful, the prophets, and

\footnotetext{
${ }^{95}$ O'Shaughnessy, The Development of the Meaning of Spirit in the Quran, 67-8.

${ }^{96}$ O'Shaughnessy, 26-31, 68.

${ }^{97}$ Ibid., 13-15.
} 
to Jesus in particular. O'Shaughnessy prefers to investigate the so called development of the term ruh rather than advance a more fruitful and necessary thematic study which would not presuppose that Muhammad was fabricating the ideological content of his own message in response to groups whom he may not have even met. 


\section{Chapter IV: Quranic images of Jesus}

The narrative about Jesus begins with Mary. She is the virgin mother of Jesus, who according to the Quran was chosen and purified, to become the agent of Jesus' birth. $^{98}$ She is given the good news of a "word from God" that will speak from the cradle and live in righteousness. Jesus will be taught the Wisdom, the Torah and the Gospel. He was a messenger gifted with signs of divine favor such as reviving the dead, animating clay birds, healing the sick, and more. According to the Quran, his message to the people of his time was to fear God and follow His teaching. The Jews of his time tried to kill him but Jesus was saved by God and taken into heaven. ${ }^{99}$ In two places in surah three the extraordinary circumstances of Jesus' birth are contextualized in terms of God's power and ability: "Jesus in Allah's sight is like Adam; He created him from dust, then He said to him: 'Be', and there he was" (3:59, 47). These verses together constitute an Islamic version of Jesus as the second Adam, with a different role in history. The connection between Jesus and Adam is made in the Quran to temper the argument that because Jesus was conceived without male agency, he is somehow really or symbolically the son of God.

An important detail about Jesus recorded in the Quran is that he spoke in defense of his mother while still in the cradle. ${ }^{100}$ In his speech he identified himself as a prophet who had been given a book (revelation) from God. Jesus concludes, "Peace be upon me the day I was born, the day I die and the day I rise from the dead." It is important to keep in mind that Jesus identified himself as a prophet almost from the day of his birth. It can be argued, and this thesis assumes as much, that he was a prophet from the moment of his birth. This premise is both substantiated by the

\footnotetext{
${ }^{98} 3: 42-60$ for the rest of this paragraph.

${ }^{99}$ Quran 4:157 and 3:55.

${ }^{100}$ Quran, 19:27-35.
} 
circumstances of his birth and is used to explain why he was born to a virgin mother. Jesus is also identified as a servant of God-4:171 and 5:17 - in verses that criticize his deification. In 5:72-77 one finds strongly worded condemnations of the incarnation and trinity:

Those who say that Allah is the Messiah, son of Mary, are unbelievers. The Messiah said: "O Children of Israel, worship Allah, my Lord and your Lord... unbelievers too are those who have said that Allah is the third of three... the Messiah, son of Mary, was only a Messenger before whom other Messengers had gone; and his mother was a godly woman.

Many of the verses about Jesus seem to be admonishing an audience to reconsider him as a human prophet, elevated in rank. Clauses such as "they both (Mary and Jesus) ate food" or "will you worship, instead of Allah, that which cannot hurt or profit you," (5:75-6) contrasts the human qualities of Mary and Jesus with the absolute transcendence of God. Orientalists are right to assume that Muhammad had no knowledge of the intricacies of Christian theology vis-à-vis the incarnation or trinity; but if we assume he had such knowledge he would still have derided these doctrines as $k u f r$, or unbelief.

There are several titles for Jesus in the Quran. He is called the Messiah eleven times, slave or creature $(a b d)$ numerous times, nabi and rasul (prophet and messenger respectively) one and ten times respectively. ${ }^{101}$ The term al- Masih ${ }^{102}$ is a loan word from Hebrew and despite the theological connotations of the reference to Jesus as Messiah the Christian significance of this title was never adopted by Muslim writers. Bayḍāwī suggested that al-Masih is simply an honorary surname of Jesus in the same way a prominent companion of the Prophet, Abu Bakr, is called as-saddiq, the

\footnotetext{
${ }^{101}$ Parrinder, 30-45.

${ }^{102}$ Arthur Jeffery, The Foreign Vocabulary of the Quran (Leiden: Brill, 2007), 265.
} 
truthful. ${ }^{103} \mathrm{Abd}$ is a term which primarily refers to the person who worships God, and the English translation 'slave/servant' is only correct when the person who is abd is $a b d$ towards God. Jesus is called a servant in connection with his identity as a prophet and messenger. Nabi and rasul are similar but not interchangeable terms. Nabi is considered less significant than rasul; a rasul is distinguished from a nabi in the sense that he comes with a law and a book. ${ }^{104}$ This distinction is not really relevant here because Jesus is designated with both titles.

Two more problematic titles attributed to Jesus are word (kalima) and spirit (ruh). They both have clear antecedents within a Christian context but are moderated in Islam with reference to Jesus. Bayḍāwī gives the standard explanation for kalima as a title for Jesus: he is called 'word' because he was created, without a father, by the divine word Kun, 'Be'. ${ }^{105}$ There are no grounds to associate the Arabic term kalima with the 'logos' of Christianity. But based on the apology proposed by Bayḍāwī there must have been Christians who made the connection in dialogue with Muslims. The distinction here is between the pre-existent logos and the word of God by which created His $a b d$ within the stream of human history. ${ }^{106}$ Needless to say logos theology would have a hard time finding supporters within Islam. By far the most problematic title for Jesus in the Quran is spirit. It is used in a number of different contexts and has a variety of meanings. In 4:171 he is identified as a "spirit from God." In the verses we will deal with later he is aided by the Holy Spirit, Gabriel, who is also instrumental in the conception of Mary. We will deal with this issue in more detail in preparation for our analysis of exegesis on the three selected verses. Two other titles

\footnotetext{
${ }^{103}$ Parrinder, 31.

${ }^{104}$ Rahman, Fazlur, Major Themes of the Quran (Minneapolis: Bibliotheca Islamica, 1989), 81-2.

${ }^{105}$ Parrinder, 45.

${ }^{106}$ David Marshall, in Rodgerson, 17.
} 
for Jesus are mithal (parable, example) and aya (sign). They are important titles because they beg the question: A sign/parable of what? We will come back to this question in the concluding section. The next section will provide some information on the further development of Islamic views - in this case polemical - towards Christianity. 


\section{Chapter V: Post-Quranic Christology: It's Polemical Context}

Jesus is prominent in the Quran. He is a prophet, elevated with the sublime titles mentioned above. Jesus was pure, a righteous servant, who performed miracles as evidence of the authenticity of his prophetic mission. He was born of a virgin mother, and they are both signs for mankind. Moreover, he is honored in Islamic mysticism as the prototypical ascetic, worshipping God for His sake alone. There is a wealth of sayings attributed to Jesus among Sufi saints and scholars, ${ }^{107}$ which show that they regarded him as an ideal of the interior life. But there has never been a detailed representation of him in the same way that hadith literature canonized the Sunna, or normative practice of the prophet Muhammad. Jesus' role in prophetic history and the significance of his life are secondary to the mission of Muhammad. In a sense, per the discussion about Islamic Christology as independent in meaning from Christian sources, the Prophet's vision and the Quranic verses represent a humanizing shift in thinking about Jesus that is substantive and intelligible within an Islamic discourse.

When the Islamic community expanded after the death of Muhammad in 632, Muslims ruled sizeable regions of the former Byzantine Empire, including their Christian communities. What we refer to as Muslim-Christian dialogue was actually a prolonged polemical debate between Christian scholars and subjects with their Muslim rulers and the Muslim scholarly community. Without giving inordinate attention to the history of Muslim-Christian relations we should mention that the main issues debated and discussed - aside from politico-military issues — related to the nature of Jesus. Christians such as John of Damascus viewed Islam as a heretical offshoot of some Christian sect. Christian polemicists tried to discredit Islam by

\footnotetext{
${ }^{107}$ See note 75 .
} 
arguing that Muhammad was the author of his religion and a false prophet. ${ }^{108}$ One form of argument that was employed by Christian polemicists was to argue that the Quran borrowed material from earlier scriptures which it (the Quran) claimed had been tampered with: tahrif. They claimed both that the use of 'corrupted' material from earlier scriptures invalidated the Quran, and that it validated, by the fact that this material was used in the Quran, the earlier scriptures, ${ }^{109}$ in this case the Gospels. The profoundly irrational nature of some arguments had positive effects: it led to a serious study of Islam by Peter the Venerable, Raymond Lull, Robert of Ketton and many others, leading to the work of Richard Burton, Renan, de Sacy, and other modern and contemporary Orientalists. ${ }^{110}$ The West, formerly Christendom, certainly is in the vanguard of research and writing on Muslim-Christian dialogue because Christians face a serious challenge from Islam concerning the figure of Jesus. Islam humanizes and assimilates Jesus as a secondary prophet to Muhammad, and, moreover, divests him of divinity and status as redeemer.

Christianity did not similarly challenge Islam because Muslims, following the Quran, viewed Christians as a legitimate community that had erred in attributing divinity to Jesus. Muslim polemics dealt primarily with the incarnation, trinity, and crucifixion and were much less bellicose and defamatory. Scholars or converts from Christianity were only interested in Christological issues to the extent that they offended their monotheistic sensibilities. Tawhid, or recognition of the absolute oneness and utter transcendence of God, was the doctrinal measuring stick by which Muslim scholars viewed other religions. The importance of this idea is precisely contextualized by V.J. Cornell: "awareness of the unitary truth of God, to the earliest

\footnotetext{
${ }^{108}$ Daniel, 80, 105.

${ }^{109}$ Daniel, 75.

${ }^{110}$ Rollin Armour Sr., Islam, Christianity, and the West: A Troubled History (Maryknoll, New York: Orbis Books, 2004), ch.6-9.
} 
companions of the Prophet Muhammad as well as to later theologians, was deemed as important as to constitute the essence of knowledge itself." ${ }^{111}$ During the foundational discourses of the first few Islamic centuries these polemical issues were of secondary importance to internal debates between emerging schools of thought. Watt argues that Christian ideas did not have a significant influence on the development of Islamic theology. Christian ideas that were discussed among Muslim scholars were based in issues arising out of an exclusively Islamic context. Theological issues that could not be referred to Quranic verses eventually disappeared from the discourse. ${ }^{112}$ There are Quranic antecedents against the incarnation, trinity, and crucifixion; thus, when Muslim scholars penned polemical treatises on these doctrines they were concerned chiefly with protecting or substantiating the Quranic verses:

O People of the Book, do not exceed the bounds of your religion, nor say about Allah except the truth; The Messiah, Jesus son of Mary, is only Allah's messenger and His word, which He imparted to Mary, and is a spirit from Him (4:171).

This verse explicitly denies the divinity of Jesus but also uses traditional Christian titles for him, such as al-Masih, kalima, and ruh. The Immaculate Conception is also implicit in calling Jesus the son of Mary. But the theological significance of these titles in Islam do not approximate to their meaning in Christianity. There is no indication that scholars sought to establish interfaith dialogue on these terminological commonalities. Polemic was used as a means of defining doctrinal boundaries and arguing for either an Islamic or Christian position. In the Ummayad and Abbasid Caliphates there was a rather large and generally respected professional class of Christians engaged in medicine, science, philosophy, and translation projects. By the late $8^{\text {th }}$ century informal conversation and theological

\footnotetext{
${ }^{111}$ V.J. Cornell in Islam: A Challenge for Christianity, ed. Hans Kung and Jurgen Moltmann (London: SMC Press, 1994), 64.

112 William Montgomery Watt, The Formative Period of Islamic Thought (Oxford: Oneworld Publications, 1998), 99.
} 
disagreement developed into well-informed written refutation of controversial doctrines. ${ }^{113}$ No issue was more controversial than the divinity of Jesus and the triune godhead.

This became a specialized discourse with a clear endgame for the Muslims: prove the truth of Quranic teachings against Christian doctrine. And, even though polemicists sought out information they could use to these ends, they never undertook a serious or prolonged study of Christianity, in either its heretical or orthodox manifestation. One logical tool that was widely used was Aristotle's principle of noncontradiction. It simply requires that a proposition cannot be both true and false with respect to a single object. Abu 'alī al-Jubbaī employs this method in his criticism of the incarnation. The unification of the human and divine son in Jesus reveals this logical impossibility because one could not both worship and be grateful to oneself. No one could make sense of the notion that the divine, eternal Word could become human; in philosophical language the essence could not be made accidental; what is transcendent and formless could not become immanent. Further:

While the power to act in God is through an eternal attribute which is identical with His essence, in humans this power is endowed by accidental attributes which are external to the essence of the being itself, and so is not permanent. But if the divine and human natures in the Messiah had a single mode of action, then the power to act in the human must have been of his own essence, and so permanent. ${ }^{114}$

Again, the aim was to demonstrate some sort of logical impossibility. The means were simple, but the results were more than satisfactory. These scholars were not necessarily interested in a detailed analysis of Christian doctrine; they were well informed to the extent that their information provided a rational basis for polemic.

\footnotetext{
${ }^{113}$ Ridgeon, 79-80.

114 David Thomas, Early Muslim Polemic against Christianity: Abu '̄̄sā al-Warraq's “Against the Incarnation” (Cambridge University Press, 2002), 47.
} 
Christian converts to Islam also participated in polemics against the incarnation and trinity. 'Alī ibn Rabban al-Ṭabar̄̄ was a Nestorian convert who wrote anti-Christian treatises. His works survive only in incomplete form and through the writings of other polemicists. They were not widely read during his life because his discussion of Christianity was more detailed and nuanced than most Muslims could understand. ${ }^{115}$

The Islamic imperative to both protect the transcendent unity of God from association of partners, shirk, as well as present a detailed and nuanced understanding of Christianity is combined in the person of Abu 'isā al-Warraq. His career represents a high point in Islamic polemics because, considering the limited aims of his project, he penned the definitive critique of the incarnation and trinity. ${ }^{116} \mathrm{He}$ integrated Aristotelian logic into his methodology. His first aim was to demonstrate that a specific Christian doctrine or the implication of a doctrine is internally inconsistent, or else contradicts another Christian doctrine. He also sought to demonstrate that a doctrine or teaching was contradictory to reason. Finally, following traditional polemic, he wanted to show that the gap between the human and divine was transgressed if Jesus, who is considered divine, lives a human life; divinity takes on aspects of His creation and is in turn shaped by it. ${ }^{117}$ Abu 'isā was concerned exclusively to undermine the underlying premise behind the Incarnation: the uniting of the transcendent with His immanent creation. He does not even attempt to address the crucifixion or Christian ideas about salvation because they are peripheral to his aim of upholding the distinctiveness of God. ${ }^{118} \mathrm{Abu}$ 'īsā's Refutation of the Christians deals with Nestorian, Jacobite, and Melkite Christianity.

\footnotetext{
${ }^{115}$ David Thomas, in Encyclopedia of Islam vol. 10 (1998), 18.

${ }^{116}$ Thomas, 3-83, on the role of Abu Isa in consolidating existing ideas into his critique of Christianity.

${ }^{117}$ Thomas, 66-67.

${ }^{118}$ Thomas, 72.
} 
He addresses his critique to doctrines that each group holds independently as well as to issues on which they agree. For example, all three groups claimed that Jesus died on the cross and was later brought back to life. He poses the question: who brought him back to life? If one answers that another revived him then it follows that Jesus is not divine because it was someone other than the Messiah that possesses divine power. ${ }^{119}$ The simplicity of his critique betrays a certain disregard for nuanced explanation and apologetic but is nevertheless satisfying, to him, and altogether productive. He employs this critical scheme on every teaching he is familiar with. His single-minded focus, at once legitimate and authentically Islamic, is to discredit and undermine any identification between the transcendent, tanzih, ${ }^{120}$ God and His creation. Many of his responses to Christian doctrinal formulations are critical of the uniting of the divine with temporal substances; 'intermingling' is an attribute of individual, contingent beings only and cannot logically be applied to the universal substance or essence, which, consistent with its otherness, cannot be divided, modified, enhanced, or quantified in any way. ${ }^{121}$ This is how the controversy over Jesus' divinity was addressed and dealt with by Muslim scholars in dialogue with Christians.

While Muslim scholars critiqued the Incarnation on the basis of a transcendent-immanent dichotomy, they attempted to discredit the Trinity as a doctrinal formulation that was pluralistic, though there were a number of Arab Christians who attempted to make this doctrine intelligible to their Muslim counterparts. ${ }^{122}$ And often their Muslim counterparts were novice students of kalam,

\footnotetext{
${ }^{119}$ Thomas, 121.

${ }^{120}$ Ayoub, A Muslim View of Christianity, 125.

${ }^{121}$ Thomas, 137-9.

122 Thomas, 12-13.
} 
or Islamic dialectical theology. In the period when the Mutazilites were active, Arabic-speaking Christians began to articulate the doctrine of the trinity in terms of God's attributes, which was essentially the theological language of Islam. Mutazilite scholars such as al-Nashi al-Akbar and Abu Ali al-Jubbai responded to these attempts by expanding the range of divine attributes beyond what was symbolized by the trinity. ${ }^{123}$ "Muslims saw no reason to limit the attributes to two, because the Quran and their own reasoning taught them that God must possess rather more than that to be the omnipotent and omniscient being they expected. For them the Christian limitation was arbitrary... there is no valid hierarchical distinction between the attributes, so that according to this logic the Godhead must either be a multiplicity of persons corresponding to the descriptive adjectives that can be predicated of him or a strict unity in which the attributes are all identical with the essence of God." 124

Arguments against the trinity by Muslim scholars and polemicists:

reflect a sense of incomprehensibility. Al-Qasim questions whether the names "father" and "son," which in normal usage denote a relationship that has a beginning in time, can apply to God in His eternity, and can therefore have any reference to God himself rather than being human inventions; Al-Kindi argues that if the hypostases are each both substance and specific characteristic they must be composite and therefore affected by an antecedent cause, and so they can not be eternal; and $\mathrm{Abu}$ Isa demonstrates at great length that whatever way the doctrine is expressed, the attempt to identify three entities with one leads to confusion and incoherence. The fundamental problem that each polemicist differently raises is that since in any description of the doctrine more than one divine entity is listed, some form of plurality is entailed and the simple unity is obliterated. So the insistent claim made by the Christians that God is one becomes meaningless. ${ }^{125}$

David Thomas concludes from his various studies on dialogue and polemics in Muslim-Christian relations that the attempts by Arab Christians to rationalize their

\footnotetext{
${ }^{123}$ David Thomas in Ridgeon, 88-91.

${ }^{124}$ Ibid, 93.

${ }^{125}$ Ibid., 86.
} 
beliefs to Muslims, and the concurrent development of dialectical theology and philosophy during the foundational discourses of Islam, both made the work of polemicists necessary and was influential in directing the discourse. Christians who attempted to rationalize the trinity to Mutazilite scholars such as al-Jubbai gave him the opportunity to practice his reasoning ability while simultaneously defending his conception of God. These exchanges are a positive contribution to the development of Islamic thought, and it allowed Muslim thinkers to expand upon Quranic criticisms of basic Christian dogma. Where the Quran says "do not say three (gods)... it is better for you. Allah is truly one God" (4:171) anyone with the requisite knowledge of Christianity could elaborate on this verse by demonstrating that Christian doctrine was inconsistent with and contradicted logic, as well as the basic requirements for a legitimate doctrine of monotheism, at least according to the theological formulations of Muslim scholars.

It is clear that in this important period of encounter between Christians and Muslims the doctrine of the Trinity occasioned much disagreement and misunderstanding. The basis of the problem was that to Muslim minds the mention of the three persons meant three separate deities, as the Quran clearly states. And Christian attempts to explain that their doctrine did not entail plurality failed completely. In whatever way they attempted to employ concepts borrowed from Islamic theology, and however well they themselves were satisfied with the new formulations in which they employed them, the end result was that they increased confusion rather than clarity... Despite these efforts of Arabic speaking Christians to explain the Trinity in terms borrowed from their neighbors, Muslims saw no reason to revise the accusation made in the Quran that the doctrine of the Trinity was essentially tritheism. Christian attempts to uphold claims to the contrary confirmed their (the Muslims) view that the doctrine inevitably led to confusion and incoherence. Such attitudes towards the doctrine changed little in subsequent centuries. ${ }^{126}$

To place these discussions in historical context it is important to note that the gradual development of dialogue and polemic between Muslims and Christians takes place

\footnotetext{
${ }^{126}$ Thomas in Ridgeon, 94-95.
} 
alongside the development of dialectical theology in Islam. Christian apologists understood this and tried to make Christian doctrines intelligible to Muslims. One writer, al-Nasibi, contrasts the dilemma of Muslim perceptions of plurality in the trinity with the problem of anthropomorphic verses of the Quran where it is stated that God has eyes, hands, and other physical properties. ${ }^{127}$ There are various approaches to this issue within Islam, but the point to be made here is that Christian scholars, very much aware of the problems inherent during the doctrinal institutionalization of a religious creed, tried to temper the rational qualifications made by Muslims against the trinity by pointing to similarly problematic issues within Islam. This exchange, characterized by polemical objectives and apologetics though it was, was an open dialogue and a sincerely engaged and substantive debate.

The product of this period in Muslim-Christian relations was the crystallization of theological boundaries between the two faiths. Christianity had come to realize that Islam was not a heretical offshoot of Christianity but a major new world religion that claimed to supersede Christianity and finalize direct revelation in human history. Moreover, subsequent events such as the Crusades and the rise of the Ottoman Empire would, in various ways, lead to a serious study of Islam in Western Christendom. In the Islamic world, Christianity was a topic of study in the service of elaborating Quranic criticism of the two major Christian doctrines discussed above. Islam was in a privileged position vis-à-vis Christianity - in the same type of relationship Christianity had with Judaism - because in its overall scheme Islam subordinates Christian claims to the authority of the Quran while teaching that Jesus was an honored prophet. I am not interested in substantiating the authenticity of Islamic arguments against Christian doctrine. I am well aware that Christian students

\footnotetext{
${ }^{127}$ Gaudeul, vol. 2, 156-163.
} 
of Islam can articulate effective apologetics in response to Islamic claims. What is critical above all else is the recognition that doctrinal boundaries articulated by Muslim writers represent an authentic expression of the theological reservations by some of the foremost exponents of Islamic thought. 


\section{Chapter VI: Post-Quranic Christology: A Matter of Theological Perspective}

Muslim scholars also had diverse opinions about the crucifixion of Jesus and how to interpret the Quranic passages that deal with this event as well as the question of his death. In their deliberations on this subject, which are continuous till this day, they open the text to multiple interpretations based on theological and philosophical predilections. No one opinion can be arbitrarily established authoritatively over another and each scholar brings a unique perspective to the interpretation of the Quran based on their personal intellectual qualities. Their ideas are also formed within a concrete historical context wherein their scholarly method and the questions they seek to answer are products of the overall development in human thought. Quranic exegetes like al-Ṭabarī and Ibn Kathir used biblical material - they also used a number of traditions from Jewish and Christian converts - to deal with the historical dimensions of Quranic verses. Contemporary scholars and writers- Ismail Ragi alFaruqi, Abbas al-Aqqad, Kamil Hussein, Ahmed Shafaat, and even authors in the polemical tradition such as Ahmed Deedat or Ata ur-Rahim - now have access to more, newer sources and a plethora of critical research on the Bible when developing ideas.

The Quranic denial of the crucifixion of Jesus is based on verse 4:157-8: "And their saying: 'We have killed the Messiah, Jesus, son of Mary and the messenger of Allah.' They neither killed nor crucified him, but it was made to appear so unto them. Indeed, those who differ about him are in doubt about it. Their knowledge does not go beyond conjecture, and they did not kill him for certain; rather Allah raised him unto Him." The problematic clause in this verse is wa lakin shubbiha lahum, it was made to appear so unto them. This was interpreted to mean that another was made to bear the image of Jesus and suffer in his stead. Ayoub refers to this as the substitutionist 
theory. ${ }^{128}$ It was initially based on a tradition transmitted from Qatada, a contemporary of the Prophet Muhammad that just before provincial authorities arrested Jesus he asked one of his disciples to take on his image and suffer in his stead. This hadith shows that the person who suffered in Jesus' place did so voluntarily, and therefore God did not do injustice to that person by allowing him to make that sacrifice. ${ }^{129}$ Another interpretation that developed from a literal reading of the Quran was that the person substituted was being punished for his involvement in Jesus' arrest. One version has the image of the person pursuing Jesus changed into his image; he is mistakenly arrested and killed. In another version Judas replaces Jesus as a punishment for having betrayed him. ${ }^{130}$ This was developed from traditions passed on from Wahb ibn Munabbih. This particular idea is further developed and is a prominent feature in the Gospel of Barnabas. ${ }^{131}$ Al-Razi, a rationalistic exegete, rejects this theory because of grammatical and historical considerations. In his view the ideas propounded by earlier scholars are altogether unsatisfactory and historically unverifiable, so that the accumulated attempts to rationalize a substitute for Jesus are inauthentic and conjectural. ${ }^{132}$ Much of the discussion of verse 4:157 is speculative, with the exception of the substitutionist theory, which is based on hadith literature.

There were a variety of interpretations of the denial of the crucifixion offered by scholars from diverse schools of thought. There were also differing opinions on the correct understanding of Jesus' death, referred to in verses 3:55, 5:117, and 19:33. While these issues are important in exegesis, the main question with regard to Jesus'

\footnotetext{
${ }^{128}$ Ayoub, 159-160.

129 Ayoub, 160. Also, 164-5, Ayoub discusses the rejection of the substitutionist theory by the Mutazilites, who questioned the theory on the theological ground that it compromised God's attribute of Justice. Az- Zamakhsharī, a Mutazilite thinker himself, rejects substitution on grammatical grounds.

${ }^{130}$ Ayoub, 162-3.

${ }^{131}$ Gaudeul, vol. 2, 192-7.

${ }^{132}$ Ayoub, 164.
} 
death and Muslim-Christian debate is whether or not Islam is open to the possibility of there being a sacrificial agent in human history. Salvation theology is denied, at least implicitly, by the Islamic rejection of the divinity of Jesus. His divinity is necessitated theologically by the requirements of salvation theology to have the agent of salvation be divine: "For God so loved the world that He gave His only begotten Son, that whoever believes in Him should not perish but have everlasting life" (John 3:16). The Quran and the community of learned scholars throughout Islamic history have rejected the Christian concept and narrative of redemption without necessarily having to address the Christian view of salvation directly. One modern scholar, Ismail Raji al-Faruqi, considers Christian concepts of salvation and offers an Islamic alternative. For Faruqi, the human predicament of suffering, alienation from God, and humanity's status as "fallen" because of original sin have no parallel or support in Islam. Man in Islam is not defective essentially, or by nature, but lives with the responsibility of khalifah, vicegerent or steward of God; "salvation is hence not in the vocabulary of Islam." ${ }^{133}$ He uses the term falah, which he defines as the "positive achievement in space and time of the divine will," ${ }^{134}$ as an Islamic counterpart to salvation. For Faruqi religion and civilization are synonymous, and the defining criteria for salvation in Islam - for surely Islam teaches of heaven and hell- is fidelity to God and a concomitant moral agency in history. The success or failure of this undertaking is the determining factor of salvation.

\footnotetext{
${ }^{133}$ Gaudeul, vol. 2, 199.

${ }^{134}$ Ibid.
} 


\section{Chapter VII: Quranic Exegetes and Exegesis}

The term spirit, ruh, is used in the Quran twenty times. ${ }^{135}$ The spirit is associated with the angels as agents of the divine will in the world. They "stand in ranks" and do not speak, wholly subservient to the will and command of God (78:38). On the night of power, laylat ul-qadr — which is during the month of Ramadan — the angels and the spirit descend from heaven to carry out the will of God for each person for the coming year $(97: 1-5) .{ }^{136}$ Other Quranic verses $(70: 4 ; 58: 22 ; 17: 85 ; 16: 2)$ speak of spirit as an incorporeal entity that carries out the will of God. This sense of spirit is considered to date from the early period in Mecca when the prophet first began to preach. The use of the term spirit is common to Semitic religions as a means to identify the agent of God's creative activity in the world; but it is likely that the use of this term in the Quran originated independently. ${ }^{137}$ Ruh is always used in the Quran in the singular; there cannot be many or multiple spirits, just one. Moreover, what we do know of the spirit, as well as what we can know is limited by God: "They ask you about the spirit. Say: 'The spirit is of my Lord's Command, and you have not been given except a little knowledge'" (17:85). This verse is interpreted to be in reference to Gabriel. ${ }^{138}$

In another sense, the term spirit is less corporeal and more ethereal or abstract: "That is how We revealed to you a spirit by Our Command. You did not know what the Book is nor what is Belief; but We made it a light, by which We guide whomsoever we wish of Our servants" (42:52); and, "He casts the spirit of His command upon whomever of His servants He wishes, to warn of the Day of

\footnotetext{
${ }^{135}$ O'Shaughnessy, The Development of the Meaning of Spirit in the Quran, 13-15.

${ }^{136}$ Nāșiruddīn Bayḍ̄̄wī, Anwār al-Tanzīl wa-asrār al-Ta'wīl, vol. 2 (Beirut: Dār al-kutub al-iilmiyah, 2006), 611.

${ }^{137}$ O'Shaughnessy, The Development of the Meaning of Spirit in the Quran, 9-10.

${ }^{138}$ O'Shaughnessy, The Development of the Meaning of Spirit in the Quran, 43.
} 
encounter" (40:15). In the exegetical literature the meaning of spirit is variously identified as Gabriel, revelation, the books revealed to earlier prophets, the Quran, or prophethood (nubuwwat). ${ }^{139}$ The general theme of the two above verses is the guidance given by God to humankind and the form of that guidance. Spirit can be taken to mean the intermediary of revelation (Gabriel), revelation as an abstract concept (wahi), the form which revelation takes, or the station of those who are entrusted to preach the message. In two verses it is the Holy Spirit (16:104) and the Faithful Spirit (26:193) which bring down revelation from God. The Holy Spirit also strengthens those that believe (16:104); and those that believe are strengthened by a Spirit from God (58:22). Note that the Spirit is generally an agent of divine commands.

More than half of the Quranic verses that mention the spirit deal with either the process by which mankind is animated spiritually or with Jesus and Mary. In verses $15: 29,32: 8$, and 38:72 mankind is said to have been formed from clay. Then, in order to bring that form to life God breathed into it, nafakha, some of His spirit. The verses from surah 15 and 38 refer specifically to the creation of Adam, the primordial man and first prophet. The verse from surah 32 refers to the creation of mankind in a generic sense, with no reference to Adam. The remaining two verses where the physical being of God's creation is animated by the creative breathing of spirit are the birth stories of Jesus in 21:91 and 66:12. The first detail one notices is that the verses in question specifically mention the chastity of Mary. Mary and her child are truly honored by these verses. More profound is the fact that the birth of her child is heralded by Gabriel (19:17). ${ }^{140}$ This might be connected to the fact that she was chaste and pure. But her child, born immaculately, is also unique in that, next to

\footnotetext{
${ }^{139}$ Ibid.

${ }^{140}$ Bayḍāwīi, vol. 2, 28.
} 
Adam, he is spoken of as a spirit from Him (God) (4:171). In the three verses we will look at Jesus is assisted or strengthened by the Holy Spirit: 2:87, 253 and 5:110. The Holy Spirit is also the agent of revelation to the prophet Muhammad (16: 104).

\section{Tabarī}

The first exegete we will look at is Abu Ja far b. Jarìr at-Tabarī. He was a devoted scholar of two monumental and still widely read works: his universal history and his Quranic exegesis, Jāmi al-bayān fì ta'wìl al-Qur'an. He brings many different traditions of the prophet to bear on the interpretation of any one verse. Sometimes he gives multiple versions of the same or a similar tradition. His dogmatic views fall within what was acceptable in the scholarly circles at the time of Ibn Hanbal and alAshari. ${ }^{141} \mathrm{He}$ was scrupulous in the choice of traditions he included in his commentary, and incorporated a wide range of material into his work. His commentary also uses some material from older or contemporary works which are now lost. ${ }^{142}$ The methodology used by al- Tabarī is al-tafsīr bi al-ma'thūr or the collection of disparate oral traditions and critical analysis of the chain of transmitters (isnad) in order to verify the authenticity of that particular tradition. ${ }^{143}$ This method of Quranic scholarship reached its zenith with at- Tabarī, whose work "inaugurates the classical era of Quranic exegesis." ${ }^{144}$ After recording the various traditions relevant to the interpretation of the verse Tabarī gives his personal, reasoned view about which interpretation is most suitable.

\footnotetext{
${ }^{141}$ C.E. Bosworth, 'Al-Ṭabarī' in The Encyclopedia of Islam (Leiden: Brill, 1998), vol. 10, 12.

142 Ibid. 10-14.

${ }^{143}$ Jane Dammen McAuliffe, Quranic Christians: An Analysis of Classical and Modern Exegesis (New York: Cambridge University Press, 1991), 19-20.

${ }^{144}$ Ibid., 21.
} 
The phrase in verses 2:87 and 2:253 which connects Jesus with the Holy Spirit

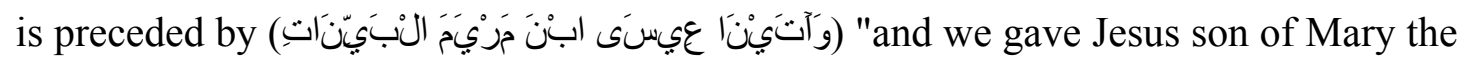
evidences." The evidences refer to the signs or miracles performed during the life of Jesus which were done in order to demonstrate to people the veracity of his claim to be a prophet. Jesus was empowered to revive the dead, breath life into the clay figurine of a bird, cure the illnesses of people whom he came into contact with, and to inform people about what is in their houses; this aspect of the evidences given to Jesus demonstrate that he had knowledge of the unseen (النغيوب). Another interpretation of the evidences is the ability of Jesus to dispute with people on the basis of the Torah and Injil. ${ }^{145}$ Disputation is not as unambiguously miraculous as curing the blind or demonstrating to people knowledge of the unseen, but the ability of Jesus to establish himself as a religious authority required evidences alongside knowledge and personal charisma.

Tabarī then cites a tradition to explain the meaning of "strengthened" in the context of the whole verse. It could mean that God strengthened Jesus by making him strong in certain characteristics in order to deal with challenges or that God assisted Jesus with tangible aid: the Holy Spirit. Most of the traditions cited by Tabarĩ identify the Holy Spirit with the archangel Gabriel. ${ }^{146}$ Another interpretation for Holy Spirit is given to the effect that the Spirit by which Jesus was aided was the Injil. Both the Quran and the Injil are spirits because they come from God or are part of His spirit. ${ }^{147}$ In this case assistance comes from the message rather than an outside agent. The identification of Spirit with the revelation is substantiated by reference to verse $42: 52$, "We revealed to you a spirit by our Command. You did not know what the book is or

\footnotetext{
${ }^{145}$ Abu Ja far b. Jarīr at-Ṭabarī. Jāmi ‘ al-bayān fì ta'wīl al-Qur'an. Beirut: Lebanon, vol. 1, 448.

${ }^{146}$ Ibid., 448-9.

${ }^{147}$ Ibid., 449.
} 
what is belief; but We made it a light, by which We guide whomsoever We wish of Our servants." Another interpretation of the Holy Spirit is as the name by which Jesus revived the dead.

Tabari's preference in interpreting this verse is that the Holy Spirit is the angel Gabriel. First, he demonstrates that the Holy Spirit can not be identified with the Injīl because in verse 5:110 Jesus is aided by the Holy Spirit and also taught the Injīl. The cause for the identification of the Holy Spirit with the Injīl is not substantial. The Injīl can be interpreted as a spirit, or as having come from the divine spirit. The identification of Injīl with the Holy Spirit is due to the fact that in the Quran God is described as holy, qudus (59:23); also, revelation is described as a spirit from God (42:52). This is why abu Zayd interprets the agent of assistance to Jesus as the Injīl. But the Holy Spirit is a title designated for an exalted servant of God, Gabriel. The choice of Gabriel as the Holy Spirit is further substantiated by the fact that it is Gabriel who teaches Jesus the wisdom and the earlier revelations. Since Gabriel is the agent through whom God communicates His message to each of the prophets his natural role would be to communicate to Jesus the content and also the context of earlier revelation. In fact, Tabarī states that the primary function of Gabriel in assisting Jesus was to teach him the Torah and Injīl, the wisdom (hikma), as well as assist him in the performance of signs, or evidences. ${ }^{148}$ Tabari does not return to the idea that the Holy Spirit is the name by which Jesus revived the dead. We can conclude that Jesus was appealing to Gabriel, the Holy Spirit, in order to assist him in performing his signs. The name itself is not intrinsically gifted with the power to perform signs but is the title of the agent of these signs: Gabriel.

In his interpretation of verse $2: 253$, which contains the exact same clause as verse 2:87, al-Tabari refers back to his discussion of that verse and the basic element

${ }^{148}$ Ibid. 449-450. 
of his exegesis: the Holy Spirit is Gabriel, Gabriel assisted Jesus in performing certain miracles and other signs which were instrumental in substantiating his prophetic claim, the revelation specific to Jesus, the Injīl, was sent down to Jesus through Gabriel, and Gabriel acted as a teacher for Jesus, teaching him the earlier revelations. His interpretation for verse 5:110 - Allah will say: "O Jesus, son of Mary, remember my grace upon you and upon your mother, how I strengthened you with the Holy Spirit, so that you could speak to the people in the cradle and as an old man; how I taught you the Book, the Wisdom, the Torah and the Gospel"- is also a concise repetition of verse 2:87. The context of this verse is a dialogue between God and Jesus wherein God recounts to him the ways and means by which He blessed him.

\section{Zamakhsharī}

The next exegete that we will look at is al-Zamakhsharì. He was both a Mutazilite thinker as well as a gifted linguist. And though the Mutazilite school has for centuries been eclipsed by the so-called ahl as-Sunna wa al-jam'a and Ashari theology, the tafsir of al-Zamakhshari is still widely read and consulted in the Muslim world because of the linguistic mastery of its author. He understands the signs entrusted to Jesus as his various miracles and the arguments he made. The signs are instrumental in validating the prophecy of Jesus. ${ }^{149}$ Jesus is strengthened by the sanctified spirit which is a spirit from God, or part of his majesty and strength. The Holy Spirit is a title specifically used to indicate its exalted status. Zamakhsharī is clear that there is not unity or fusion between Jesus and the Holy Spirit. ${ }^{150}$ Zamakhshari also mentions the interpretation that identifies the spirit with the Injīl as well as the name by which Jesus revived the dead, but does not give further comment.

\footnotetext{
${ }^{149}$ Al- Zamakhsharī. Al-Kashshāf 4 vols. (Beirut: Dār al-kutub al-'ilmiyah, 2006), vol. 1: 162.

${ }^{150}$ Ibid. 163.
} 
For verse 2:253 Zamakhshari does not provide an explanation; the interpretation of verse 2:87 applies to both verses.

The context of the dialogue between Jesus and God in verse 5:110 is the opposite positions taken by the Israelites towards Jesus. Some ridiculed his signs as mere magic, thereby rejecting his prophetic claim. Others divinized him. He will be asked about this and the answer is already given in the following verses: Jesus will deny having claimed divine status and defer judgment to God, in whose knowledge the truth is clear. In his interpretation of verse 5:110 Zamakhsharī defines ruh alqudus as the agent of revelation; the adjectival use of qudus, holy, signifies purity from sin and wrongdoing. ${ }^{151}$ This is demonstrated by the fact that Jesus speaks to the people from the cradle, while a baby. The one that assisted Jesus in all this is Gabriel. ${ }^{152}$ Gabriel is instrumental in helping Jesus perform the various signs during his life that substantiate his position as messenger of God. Additionally, Gabriel assumes his role as guide and teacher of Jesus in the beginning of his life, while he is still in the cradle.

\section{Baydāwī}

Bayḍāwì's short tafsir of the Quran is also a very popular work. He adopts many of the opinions found in the work of Zamakhsharī, but edits some material which was not accepted in Ashari theology. The signs which Jesus performed are his miracles: giving life to the dead, healing the blind and lepers, informing people about the unseen; his sign could also be the Injīl. The Holy Spirit, again, is Gabriel. ${ }^{153}$ Bayḍāwī identifies Jesus as ruh, spirit, because he is pure and untouched by shaytan. Baydāwī also considers the Injīl and the name with which Jesus raised the dead as

\footnotetext{
${ }^{151}$ Ibid. 676.

${ }^{152}$ Zamakhsharī, 675-6.

${ }^{153}$ Nāṣiruddīn Bayḍāwī, Anwār al-Tanzīl wa-asrārr al-Ta'wīl, 2 vols. ((Beirut: Dār al-kutub al-'ilmiyah) vol. $1,74,288$.
} 
possible descriptions for ruh al-qudus, ${ }^{154}$ though he specifies that his preference is to identify Gabriel with the Holy Spirit. In his interpretation of verse 5:110 he identifies the Holy Spirit with Gabriel or the agent of revelation. ${ }^{155}$ Further elaboration on the nature of the Holy Spirit is that it is eternally pure.

\section{$\underline{\text { Al- Razī }}$}

Fakhr al-Razī is the last Quranic exegete whose work we will look at. In many ways he offers the most interesting interpretation of the three verses because he was more of a philosopher than an orthodox exegete like Ṭabarī, who restricted himself to the use of hadith and recognized traditions. Al-Rāzī gives his interpretation of the verses as layers of arguments (or just some basic considerations), some subsequent arguments, qualifying positions, and counter arguments. ${ }^{156}$ Al-Rāzī is an important figure to consider in this thesis because he develops interpretation beyond the level of plain, evident meaning. Al-Rāzì is an orthodox scholar but has the philosophical breadth to discern deeper meanings within the verses he interprets. The product of his intellectual activity is tafsir and $t a^{\prime}$ wil.

The Difference between tafsir and ta'wil, according to some commentators, is that tafsir is concerned primarily with the transmission of tradition, whereas $t a^{\prime}$ wil is concerned with the deeper comprehension of the inner meaning of the sacred text. Ta'wil must not, however, do violence to the literal sense or meaning of a verse or passage of the Quran or to the prophetic tradition because the sunna is the first interpreter of the Quran. ${ }^{157}$

Al-Rāzī does not differ from the other exegetes on any major issue, but he does draw conclusions which require a deeper reading of the verses in question and a general reference to other Quranic or extra-traditional material.

\footnotetext{
154 Ibid. 74.

${ }^{155}$ Ibid. 288.

${ }^{156}$ Mahmoud Ayoub, The Quran and its Interpreters (New York: SUNY Press, 1984), 5.

${ }^{157}$ Ibid., 21.
} 
Verse 2:87 begins with a statement about the prophet Moses and the successive prophetic missions sent by God. Al-Rāzī comments that after having been given divine guidance (from Moses) the ancient Hebrews began to disagree among themselves on religious issues. Their quarrels led to civil strife and oppression, as well as to a general perversion of religious sentiment and action. ${ }^{158}$ They had traded the life of this world for the hereafter (2:86). So God sent messengers, one after the other, in order to refresh the message of Moses and provide guidance on that basis. This was the case from the time of Moses until the advent of Jesus. All previous messengers renewed the Law of Moses; they could not augment, add, or change the Torah revelation; they were restricted by the contents of the Mosaic discourse but are called to bring people to the worship and submission to God. God did not send messengers unless they were to preserve or give witness to what had previously been forgotten or extinguished (اندرس) from the original message of Moses. This applies to all prophets from the time of Moses until the prophetic calling of Jesus. He is distinguished from his predecessors by bringing a new Sharia, a new law or path. This necessitated that he come with proofs on which to base his claims. Al-Rāzī gives a number of different interpretations for bayinnāt including the various miracles he performed during his private life and public ministry and the Injīl. One could also combine the two and argue that the miracles serve to demonstrate Jesus's divine mandate while the Injīl was the new Sharia. ${ }^{159}$

All-Rāzī gives a number of different definitions for Ruh al-Qudus, many of which we have already seen. The most widely accepted interpretation for Ruh alQudus is Gabriel. The title, in addition to being a means of identification, is also one of honor, esteem, and rank. Gabriel's exalted rank can be said to rest on two pillars.

\footnotetext{
${ }^{158}$ Fakhr al-Razī, Al-Tafsīr al-Kabīr (Tehran: Dār al-Kutub Al-'ilmiyyah, n.d.), vol. 3: 175-6.

${ }^{159}$ Ibid., 175-6.
} 
First, he is the intermediary between God and the prophets of God. He communicates the revelation of God to those chosen messengers. This is his unique role and specific trust. ${ }^{160}$ During the life of Jesus it is Gabriel who assisted him in the performance of miracles. He is also the teacher of Jesus, through whom God teaches the Torah, Injīl, and the Wisdom (5:110). Al-Rāzì states that it is the spirit which gives life to men. ${ }^{161}$ There is no uniform interpretation of Ruh among the exegetes examined in this thesis. But while the Injīl is considered as a possible meaning for $r u h$, it is recognized that Ruh al-Qudus (Gabriel) is the one that communicates the Injīl, regardless of whether or not we identify the Injīl as a spirit or as a book.

Secondly, Gabriel is the one who brought the spirit of Jesus to Mary through the agency of his breath, nafkh. ${ }^{162}$ We can view the verb "to breath" as a symbolic representation of the creative act of giving life and animating corporeal objects. This is what Gabriel does with Mary because she was a virgin. Here we can see that the role of servant of God and most highly exalted of the angelic beings is based upon the dynamic of honor and responsibility. Gabriel is so honored with the title Qudus and he is correspondingly tasked with supporting the messengers of God during their ministry. Moreover, Gabriel is holy in his very essence. Al-Rāzī uses the term to indicate further the substance and purpose of Gabriel. He is said to be luminous- - in that he is, in differentiation from the other angels, pure spirit. He is also responsible for bringing spiritual success to those whom he assists, or making them strong. ${ }^{163}$ In his interpretation of verse

\footnotetext{
${ }^{160}$ Ibid, 177.

${ }^{161}$ Ibid., 177.

162 Ibid, 178.

${ }^{163}$ Ibid., 177.
} 
2:253 al-Rāzī repeats some of the same ideas mentioned with verse $2: 87 .{ }^{164}$ Al-Rāzī signals his preference for Gabriel as the identity of the Holy Spirit by quoting verse 16:102, which identifies the Holy Spirit as the agent of revelation. The other interpretations are acceptable in a general sense because in each one the ruh, spirit, is understood as a wind, الريح. Yet Gabriel is honored with the title Qudus specifically. ${ }^{165}$

In verse 5:110 al-Rāzī mentions that the background of the verse is related to the consequences of having the wrong idea of Jesus. This is why the verse is set on the Day of Judgment, when God will ask Jesus:

O Jesus, son of Mary, remember my grace upon you and upon your mother, how I strengthened you with the Holy Spirit, so that you could speak to people in the cradle and as an old man; how I taught you the book, the wisdom, the Torah and the Gospel; and how, by My leave you created out of clay the likeness of a bird, and breathed into it, and then, by My leave, it turned into a bird. And you could heal the blind and the leper by My leave and you could raise the dead by My leave. And [remember] how I restrained the Children of Israel from harming you, when you brought them the clear signs; whereupon the unbelievers among them said: "That indeed is nothing but manifest sorcery."

The overall context of the verse draws attention to the two aspects in which people misapprehended Jesus. The first is the disbelief of the Tribes of Israel in mocking the signs with which Jesus substantiated his apostleship. The following verses in the surah are critical of his eventual deification. ${ }^{166}$ Al-Rāzī gives what can best be called an esoteric interpretation, $t a^{\prime}$ wil, of this verse.

For al-Rāzì spirits (الرواح) have essentially two different natures: they can be pure and numinous or wicked and tyrannical (in this sense it can rule over ones self or be a means to try to rule over others). It can be radiant or dim. There is light and

\footnotetext{
${ }^{164}$ Al-Razī. Al-tafsīr al-kabīr (Tehran: Dār al-Kutub Al- 'ilmiyyah, n.d.) vol. 6, 203.

${ }^{165}$ Al-Razī, vol. 3: 177.

${ }^{166}$ Al-Razī, Al-tafsīr al-kabīr (Tehran: Dār al-Kutub Al-'ilmiyyah, n.d.). vol. 12, 122-124.
} 
darkness interacting within this dynamic. Jesus is significant in the fact that he is wholly endowed with the pure, numinous aspect of spirit. This begins to clarify a bit more the specific relationship between Jesus and Gabriel. Humanity partakes of both aspects of the spiritual but Gabriel is purely numinous. ${ }^{167}$ Al-Rāzī states that Gabriel is designated with the title qudus because he was created from pure light. ${ }^{168}$ The connection between the two seems to be based on this dynamic. From this it is probable that Gabriel assists Jesus in maintaining purity as well as helping him to perform miracles with which to substantiate his prophetic function. Al-Rāzī directly connects the purity of Gabriel to Jesus and his mission. Jesus, a purely numinous being, is assisted by Gabriel; something unique to him. No other prophet before or after possessed such qualities. Again, Jesus is taught two revelations, the Torah and Injil, as well as hikma or wisdom. ${ }^{169}$ What is implied here is that he is taught through Gabriel the written word as well as the hidden, secret meanings: the esoteric aspects about the world. He is in command of those sciences which are sought after by the learned; but in his case this knowledge is vouchsafed to him by Gabriel, who was with him. This kind of knowledge is only given to the elite among the prophets.

All of the exegetes considered here agree that the designation of Holy Spirit belongs to the angel Gabriel. He is distinguished as the most powerful of all the angels. He is also the agent of revelation between God and His messengers. The use of the term holy, qudus, signifies purity. The exegetes all conform to the same narrative that it is Gabriel who assists Jesus with the performance of miracle, and these miracles are broadly considered to be a means by which Jesus demonstrates to his people that he was a messenger of God. Only al-Rāzī mentions the function of

\footnotetext{
${ }^{167}$ Ibid. 125.

${ }^{168}$ Razī, vol. 3, 177.

${ }^{169}$ Ibid. $125-6$.
} 
these miracles. According to him, they were used because he was tasked by God to bring a new shariah, way or law, to the Israelites, abrogating or replacing the Law of Moses. He is also distinguished by the fact that he elaborates on the nature of the Holy Spirit, saying that it was created from a numinous substance and that it was absolutely pure. 


\section{Chapter VIII: Conclusion}

This thesis began as an attempt to make a substantive contribution to an Islamic Christology, which is an understanding of the message and mission of Jesus in Islam. Yet, because Jesus is the central figure of another great religious tradition I attempted to deal with the implications of an Islamic Christology that in many instances is at odds with Christian views, specifically in terms of his mission-as savior or prophet - and his divine status. These two positions are central to any Christian theology. Islam does not address the issue of salvation through Jesus because salvation comes from God alone and there are other mechanisms by which the believer achieves salvation, mainly through repentance and the mercy of God. Divinity is precluded by reference to Jesus as a prophet and servant. And his sonship is specifically denied in almost any passage in which he is spoken of.

I wanted to address the issue of borrowing on the part of the prophet Muhammad of ideas about Jesus from various Christian communities. The task itself is daunting because the evidence does not provide the foundation for solid conclusions as to what he knew and from whom. Moreover, one could question the usefulness of trying to locate the sources of the Prophet Muhammad's ideas when he claimed to receive revelation from an angel. But there are some legitimate reasons for addressing the issue. First, it has been a source of polemical rejections of the veracity of the prophet from the beginning of his prophetic ministry. ${ }^{170}$ Later, the argument was made by John of Damascus that Muhammad was taught by a desert monk, and that he used these ideas to fabricate his religion. ${ }^{171}$ The argument for the prophet as an opportunistic charlatan dates to the early years of his public life in Mecca but is also

\footnotetext{
${ }^{170}$ Quran 41:43 and 46:9.

${ }^{171}$ Norman Daniel, Islam and the West: The Making of an Image (Oxford: Oneworld Press, 1993).
} 
present in Christian polemic against Islam. It relates to the question of Islamic Christology because the prophet did travel in Christian areas of the Near East and many of the Quranic verses about Jesus are also found in the bible and extra-biblical texts. The argument can be made that the prophet became familiar with a variety of different ideas about Jesus during his travels to Syria and his periodic sojourns to Hira, and that he later used these ideas to formulate the Quranic verses about Jesus.

In western academia these approaches are standard. They are part of the historical attempt to understand the process by which ideas are transmitted, transformed, and given value by great leaders and thinker. With respect to the Quranic narrative of Christ there can be no absolute certainty about how and from whom the information we find in the Quran is derived-keep in mind that revelation is not considered a disinterested explanation in the modern academic discourse, though the character of the prophet is rarely ever maligned or slighted by writers researching possible influences on him. What we do have are textual parallels of Quranic verses and various ideas current in the Near East just before the advent of Islam. Many of them are found in the Quran and they constitute the Quranic/Islamic Christology. Moreover, because the Quran is a sacred text and the foundation on which Muslims build their understanding of Jesus - as well as of everything else - the influences on the text, its context, and the intended audience are vital elements in having a comprehensive understanding of the meaning of the Quranic verses.

The prophet had close relations with notable figures with knowledge of Christianity. Bahira recognized the sign of prophethood on Muhammad while he was still an adolescent. Waraqa was a Christian who was related to the prophet through Khadija. He also recognized that the experiences of the prophet were authentic and that Muhammad would have to suffer persecution. Another Christian, Salman, was actively searching for the prophet and eventually joined the nascent Muslim 
community in Medina. The prophet had also sent a group of Muslims from Mecca to Abyssinia in search of refuge from persecution. There was undoubtedly an exchange of ideas which prompted a group of Abyssinian Christians to visit the prophet in Mecca. The other major area of contact was from the Christian community of Najran. They had friendly relations with the prophet after he immigrated to Medina. The mubahala occurred during a debate between the prophet and representatives of this community.

The context within which the Quranic Christology unfolds is first exclusively pagan. The narrative is therefore descriptive, calling the early community to hear about and reflect on the lives and tribulations of other prophets. In Medina there is an increase in the frequency of contacts between the prophet and Christians from Najran as well as Muslims from Abyssinia. The content of the verses about Jesus begin to regularly include denials of his divinity and reminders of his humanity and servitude towards God. It is clear that these denials are directed at groups who were interacting with the Prophet. The mubahala stands out as a defining event in the Quranic discourse on Jesus; the controversy between the prophet and the Christian community of Najran was occasioned by irreconcilable Christologies. The result of the debate is a call to God to judge between the two parties. This shows the exclusive nature of both Islamic and Christian claims on the person of Jesus.

The first part of this study was interested in noting parallels between the Quranic Jesus and ideas circulating in regions the Prophet Muhammad visited, ideas he may have encountered, ideas that, per Andrae, lay dormant in his mind until his angelic visitation. But far more provocative is the notion, articulated by Zaehner, that the prophet was really trying to validate the divinity of Jesus, but that he was unable to adequately express this due to personal ignorance of Jesus and orthodox Christian doctrine. Zaehner had read the denials of sonship as a denial of a carnal act on the part 
of God - though the Gospel of John refers to Jesus as having been begotten of Godwhich he explained as actually applying to pagan misapprehensions of divine activity in the world. Zaehner was then able to read the Quranic discourse on Jesus from a Christian perspective, explaining away substantive differences as an unfortunate sideeffect of alienation on the Prophet Muhammad's part from authentic instruction.

The approach of Zaehner has been heavily criticized by other writers in the field of Muslim-Christian Relations, ${ }^{172}$ but it is noteworthy for the fact that it is an attempt to syncretize the Quranic Jesus with Christian theology. Zaehner was able to introduce and justify an interpretatio Christiana —one quite at odds with the overall Quranic discourse and Islamic tradition - on the basis of a historical reading of the prophet's life. The assumption - the epistemological privilege which he exercises - is that the prophet must have derived his knowledge from someone he met during his early life and during the course of his prophetic mission. Because the presumption of borrowing is taken for granted Zaehner felt justified in reinterpreting the Quranic verses about Jesus opposite the intended meaning. He was correct in stating that the prophet did not have a nuanced theological understanding of Christianity, and that what information he may have had was only oral and incomplete. Yet, he does not allow that the Quran is offering a unique vision of Jesus guided by specifically Quranic principles.

The Quranic principles which guide our understanding of Jesus are the transcendent unity of God and His various modes of action in the world and communication with man, specifically through prophets. Jesus is one such prophet. In the Quran he is said to have been strengthened by the Holy Spirit. In the Quran the Holy Spirit is identified as the agent of revelation (16:104); this agent is also

\footnotetext{
${ }^{172}$ Leirvik, Oddbjorn. Images of Jesus Christ in Islam (Uppsala: Studia Missionalia Upsaliensia, 1999). Robinson, Neal. Christ in Islam and Christianity (Albany: SUNY Press, 1991).
} 
described as a faithful spirit (26:193). The four exegetes consulted above have unanimously identified the Holy Spirit with the angel Gabriel, though there were other opinions in circulation. His function in the life of Jesus was to teach him revelation as assist him in the performance of miracles. Al-Rāzī offered a deeper interpretation of the relationship between Jesus and Gabriel, saying that all men were subject to degrees of spiritual purity: from pure to outright iniquitous. Jesus is distinct in that his spirit is pure without the possibility of taint; so is Gabriel. 


\section{BIBLIOGRAPHY}

Ajijola, A.D. The Myth of the Cross. Delhi: Rightway Publications, 2002.

Andrae, Tor. Muhammad: The Man and His Faith, trans. Theophil Menzel. Salem, NH: Ayer Company Publishers Inc., 1971.

Armour Sr., Rollin. Islam, Christianity, and the West: A Troubled History. Maryknoll, NY: Orbis Books, 2004.

Ata ur-Rahim, Muhammad. Jesus: Prophet of Islam. Elmhurst: NY: Tahrike Tarsile Quran Inc., 1991.

Ayoub, Mahmoud. A Muslim View of Christianity: Essays on Dialogue, ed. Irfan A Omar. Maryknoll, NY: Orbis Books, 2007.

-------. "Towards an Islamic Christology: An Image of Jesus in early Shia Muslim Literature." Muslim World 66 (1976): 163-188.

-------. "Towards an Islamic Christology II: The Death of Jesus, Reality or Delusion." Muslim World 70 (1980): 91-121.

-------. "Jesus the son of God: A study of the terms ibn and walad in the Quran and Tafsir Tradition," in Christian Muslim Encounters, ed. Y Haddad and WZ Haddad, Gainesville: University of Florida Press, 1995.

Baillie, Donald M. God was in Christ. London: Faber \& Faber, 1948.

Brown, Raymond E. An Introduction to New Testament Christology. New York: Paulist Press, 1994.

Charfi, Abdelmajid. "Christianity in the Quran Commentary of Tabarī." IslamoChristiana $6(1980)$.

Cohn-Sherbok, Dan, ed. Islam in a World of Diverse Faiths. New York: St. Martins Press, 1997.

Cragg, Kenneth. Jesus and the Muslim: An Exploration. Oxford: Oneworld Press, 1985.

-------. Muhammad and the Christian: A Question of Response. Oxford: Oneworld Press, 1999.

-------. The Event of the Quran: Islam in it's Scripture. Oxford: Oneworld Press, 1977.

Crook, Jay R. The Bible: An Islamic Perspective: Jesus. Chicago, Illinois: ABC International Group, 2005.

Daniel, Norman. Islam and the West: The Making of an Image. Oxford: Oneworld Press, 1993. 
Al-Faruqi, Ismail Ragi. Islam and Other Faiths. Leicester, UK: The Islamic Foundation, 1998.

-------. Christian Ethics: A Historical and Systematic Analysis of Its Dominant Ideas. Montreal: McGill University Press, 1967.

Ford Jr., F Peter. The Genius of Christ, translation of Abbas Mahmoud al-Aqqad's Hayat al-Masih. Binghamton, NY: Institute of Global Cultural Studies (IGCS), Binghamton University, 2001.

--------. "The Quran as Sacred Scripture: An Assessment of Contemporary Christian Perspectives." The Muslim World 83 (1993) no. 2: 142-164.

--------. "Al-Aqqad's The Genius of Christ re-visited." The Muslim World 91 (2001): 277-292.

Gaudeul, Jean-Marie. Encounters \& Clashes: Islam and Christianity in History, 2 vols. Rome: Pontificio Istituto di Studi Arabi e Islamici.

Geagea, Rev. Nilo. Mary of the Quran: A Meeting Point between Christianity and Islam. New York: Philosophical Library, 1984.

Goddard, Hugh. A History of Christian-Muslim Relations. Chicago: New Amsterdam Books, 2000.

--------. "An Annotated Bibliography of Works About Christianity by Egyptian Muslim Authors (1940-1980)." The Muslim World 80 (1990): 251-277.

Green, Joey, ed. Jesus and Muhammad: The Parallel Sayings. Berkeley, California: Ulysses Press, 2003.

Griffel, Frank. "On Fakhr Al-Din Al-Razi's Life and the Patronage he Received." Journal of Islamic Studies 18 no. 3: 313-344.

Guillaume, Alfred. The Life of Muhammad: A Translation of Ibn Ishaq's Sirat Rasul Allah. Karachi, Pakistan: Oxford University Press, 2006 (nineteenth impression).

Hussein, M. Kamel, trans. Kenneth Cragg. City of Wrong. Oxford: Oneworld Press, 1994.

Ibn al-Arabi, trans. R.W.J. Austin. The Bezels of Wisdom. Mahwah, NJ: Paulist Press, 1980.

Jeffery, Arthur. A Reader on Islam. Salem, NH: Ayer Publishing Company, 1987.

-------. The Foreign Vocabulary of the Quran. Leiden: Brill, 2007 (reprint).

Khaki, G.N. "Muslim Historiography: A Study of Al- Țabarī 'sMethodology." Islam and the Modern Age (2002): 9-26.

Khalidi, Tarif. The Muslim Jesus. Cambridge, Massachusetts: Harvard University Press, 2001. 
King, James Roy. "Jesus and Joseph in Rumi’s Mathnawi." Muslim World 80 (1990) no. 2: 81-95.

Kung, Hans and Jurgen Moltmann, eds. Islam: A Challenge for Christianity. London: SMC Press, 1994.

Lampe, G.W.H. God as Spirit. Oxford: Clarendon Press, 1977.

Leirvik, Oddbjorn. Images of Jesus Christ in Islam. Uppsala: Studia Missionalia Upsaliensia, 1999.

Lewisohn, Leonard, ed. The Heritage of Sufism, vol. 1-3. Oxford: Oneworld Press, 1999.

Lings, Martin. Muhammad, His Life Based on the Earliest Sources. Rochester, Vermont: Inner Traditions International, 1983.

McAuliffe, Jane D. Quranic Christians: An Analysis of Classical and Modern Exegesis. New York: Cambridge University Press, 1991.

Moucarry, Chawkat. The Prophet and the Messiah: An Arab Christian Perspective on Islam and Christianity. Downers Grove, Illinois: Intervarsity Press, 2001.

Muhammad Ali, Maulana. Muhammad and Christ. Lahore: Ahmadiyya Anjuman, 1993.

Muhibbu-Din, Murtada A. "Imam Fakhr Al-Din Al-Razi Philosophical Theology in AlTafsir Al-Kabir." Hamdard Islamicus 17 no.3: 55-84.

Nasr, Seyyed Hossein. "Islamic-Christian Dialogue: Problems and Obstacles to be Pondered and Overcome." The Muslim World 88 (1998) no. 4: 218-237.

Newman, N.A. The Early Christian-Muslim Dialogue: A Collection of Early Documents from the First Three Islamic Centuries (632-900AD). Hatfield, PA: Interdisciplinary Biblical Research Institute, 1993.

Nurbakhsh, Javad. Jesus in the Eyes of the Sufis. London: Khaniqahi-Nimatullahi Publications, 1983.

O’Collins S.J., Gerald. Christology: A Biblical, Historical, and Systematic Study of Jesus. New York: Oxford University Press, 1995.

O'Shaughnessy, Thomas J. The Word of God in the Quran. Rome, Biblical Institute Press, 1984.

-------. The Development of the Meaning of Spirit in the Quran. Rome: Pont. Institutum Orientalium Studiorum, 1953.

Peters, F.E., ed. The Arabs and Arabia on the Eve of Islam. Ashgate Publishing Limited, 1999.

-------. Muhammad and the Origins of Islam. Albany: SUNY Press, 1994.

Parrinder, Geoffrey. Jesus in the Quran. Oxford: Oneworld Publications, 1995. 
Phipps, William E. Muhammad and Jesus: A Comparison of the Prophets and their Teachings. New York: Continuum Publishing Company, 1996.

Qaim, Mahdi Montazir. Jesus through the Quran and Shiite Narrations. Elmhurst, NY: Tahrike Tarsile Quran Inc., 2005.

Quran, trans. Majid Fakhry. NY: New York University Press, 2000.

Rahman, Fazlur. Major Themes of the Quran. Minneapolis: Bibliotheca Islamica, 1989.

-------. Prophecy in Islam. Chicago: University of Chicago Press, 1979.

Raisanen, Heikki. "The Portrait of Jesus in the Quran: Reflections of a Biblical Scholar." The Muslim World 70 (1980) no. 2: 122-133.

Renard, John. "Jesus and the other Gospel Figures in the Writings of Jalal al-Din Rumi." Hamdard Islamicus 10 no.2: 47- 64.

Roberts, Nancy N. "Reopening the Muslim-Christian Dialogue of the $13-14^{\text {th }}$ Centuries: Critical Reflections on Ibn Taymiyyah's Response to Christianity in Al-Jawab AlSahih li man Baddala Din al-Masih." The Muslim World 86 (1996) no. 3: 342-366.

Robinson, Neal. Christ in Islam and Christianity. Albany: SUNY Press, 1991.

-------- "Fakhr Al-Din Al-Razi and the Virginal Conception." IslamoChristiana 14 (1988): 1-16.

-------. "Creating Birds From Clay: A Miracle of Jesus in the Quran and in Classical Muslim Exegesis." The Muslim World 79 (1989) no. 1: 1-13.

Ridgeon, Lloyd ed. Islamic Interpretations of Christianity. New York: St. Martin's Press, 2001.

Robson, James. Christ in Islam. California: Bardic Press, 2006.

Schimmel, Annemarie. And Muhammad is His Messenger. Chapel Hill: The University of North Carolina Press, 1985.

-------. The Mystical Dimension of Islam. Chapel Hill: The University of North Carolina Press, 1975.

--------. "Jesus and Mary as Poetical Images in Rumi’s Verse." In Christian-Muslim Encounters, by Yvonne Haddad. Gainesville: University Press of Florida, 1995.

Shehadeh, Imad N. "Additional Reasons for Islam's Rejection of Biblical Christology." Bibliotheca Sacra 161: 398-412.

Thomas, David. Early Muslim Polemic against Christianity: Abu Isa al-Warraq's "Against the Incarnation." Cambridge University Press, 2002.

Van Gorder, A. Christian. No God But God: A Path to Muslim-Christian Dialogue on God's Nature. Maryknoll, NY: Orbis Books, 2003. 
Van Koningsveld, P.S. "The Islamic Image of Paul and the Origin of the Gospel of Barnabas." JSAI 20 (1996): 200-228.

Watt, William Montgomery. The Formative Period of Islamic Thought. Oxford: Oneworld Publications, 1998.

Wismer, Don. The Islamic Jesus: An Annotated Bibliography of Sources in English and French. New York: Garland Reference Library of the Humanities, 1977.

Zaehner, R.C. At Sundry Times: An Essay in Comparative Religions. London: Faber and Faber, 1958.

Zahniser, Mathias. "The Forms of Tawaffa in the Quran: A Contribution to ChristianMuslim Dialogue." The Muslim World 79 (1989) no. 1: 14-24.

Zebiri, Kate. Muslims and Christians Face to Face. Oxford: Oneworld, 1997.

-------. "Contemporary Muslim Understanding of the Miracles of Jesus." Muslim World 90 (2000): 71-90.

Zwemer, Samuel M. The Moslem Christ. London: Olphant, Anderson, and Ferrier, 1912.

-------- "The Allah of Islam and the God of Jesus Christ." Theology Today (1908) 64-77. 